\title{
MEVLÂNÂ CELÂLEDDIN-i RÛMî'NiN NAFS KAVRAMINA GETiRDiĞi METAFORIK YAKLAŞIMLAR
}

\section{Metaphorical Approaches to the Notion of Nafs by Mevlana Celaleddın Rumi \\ Dr. Adem ÇATAK}

\begin{abstract}
ÖZ
Nefs kavramı, Mevlânâ'nın tasavvuf anlayışının merkezî noktalarından birini oluşturur. Esasen tasavvuf düşüncesinin oluşumundan günümüze kadar nefs kavramı, tasavvufun önemli tartışma konularından biridir. Mevlânâ da nefs kavramı çerçevesinde farklı yorumlarda bulunmuştur. Nefsin mahiyeti ve nefs terbiyesi onun nefs hakkındaki düşüncesinin temel konu başlıklarıdır. Mevlânâ nefs kavramını değişik bağlamlarda açıklamak üzere metaforlardan yararlanmıștır. Bu makale Mevlânâ'nın nefs hakkında ortaya koyduğu metaforik anlatımları incelemeyi amaç edinmiştir. Bu yönüyle çalışmamız, Mevlânâ'nın eserlerinde kullandığı dilin edebî inceliklerinin daha iyi anlaşlabilmesi ve böylece onun düşüncelerinin daha iyi anlaşılmasına katkı sağlamayı hedeflemektedir.

ABSTRACT

The concept of nafs (self) constitutes one of the central points of Mevlânâ's understanding of Sufism. Essentially, the idea of nafs has been one of the important topics of discussion since formation of Sufi mysticism to the present. Mevlânâ added to this literature by his own interpretations. His idea of the nafs is based on the concepts of the nature of self and its education. He employed metaphors to explain the concept of nafs in different contexts.

This article aims to examine those metaphorical narratives put by Mevlânâ. From this aspect, our work is intended to pave the way for a better understanding of the literary graces of the language applied in the works of Mevlânâ, and thus to contribute to a better understanding of his ideas.
\end{abstract}

Anahtar Sözcükler: Mevlânâ, Nefs, Metafor.
Key Words: Mevlânâ, Nafs, Metaphor.

\section{Giriş}

Tarih boyunca düşünürler fikirlerinin daha iyi anlaşılmasını temin amacıyla edebi sanatlardan yararlanmışlardır. Metaforik anlatım da düşünürlerin fikirlerini ortaya koymada tercih ettikleri bir yöntemdir. Soyut kavramların somutlaştırılması veya bundan daha öte bir zenginlik kazanması için farklı kelimelerin ödünç alınması büyük önem arz eder. Bu yüzden mutasavvife de metaforik anlatıma sıkça başvurmuştur. (Cebecioğlu 1998: 128) Bu anlatım tarzında, çoğunlukla görünür dünyada yer alan motiflerden (tabiat, bitki, hayvan vb. unsurlardan) hareketle, duyu organlarıyla algılanıp tecrübe edilemeyen konular izah edilmeye çalışılmıştır (Ögke 2007: 20). 
Metafor kelimesi, bir edebiyat terimi olan istiarenin anlamdaşı olarak kullanılır. Yunanca "öte" anlamına gelen meta sözcüğü ile "taşımak, aktarmak, götürmek" manasındaki phore kelimelerinin bileşiminden oluşmuştur. (Edward 1972: 284) Metafor, "Bir deyimi/ifadeyi, anlamlı bağlantısı olan bir başka deyim/ifade ile mecazî olarak anlatmak" şeklinde tanımlanır. (Güçlü vd. 2002: 458; Çağbayır 2007: 3173) Metafor; bir şeyi veya bir fikri ona çok benzer niteliklere sahip başka bir şey ile genelde "gibi" ve "benzer" sözcüklerini kullanmaksızın istenen tanımlamayı yapmak, anlatıma üslup güzelliği ve kolaylığı katmak için kullanılan sözcük ya da sözcük kümesidir. Başka bir deyişle metafor; bir kavramı, kelimeyi, terimi, olguyu daha güzel ve iyi anlatmak amacıyla, başka bir anlamda olan bir sözcükle, ilgi kurularak benzetme yoluyla kullanılmasıdır (Aydın 2006: 10).

Mecaz, istiare, teşbih, kıyas, mesel, kinaye ve sembolik imgelem gibi edebî söz sanatlarını da içine alan metafor, daha çok şiir ve belagat alanlarında kullanılan edebî bir sanat olarak görülmekle birlikte, felsefe ve düşünce alanında kendisine sıkça başvurulan bir anlatım biçimi olarak karşımıza çıkmaktadır (Ögke 2007: 20).

Tasavvufî düşüncenin en etkin isimlerinden biri olan Mevlânâ da Mesnevî adlı eserinde metaforik anlatım metodunu çokça kullanmışır. Mesnevînin temel anlatım biçimi metaforiktir. (Nesterova 2011: 6) O düşüncelerini açılarken metaforlardan yararlanmayı bir sanat hâline getirmiştir. Bir dil üstadı olan Mevlânâ'nın eşsiz eseri Mesnevî́de metaforik anlatıma sıkça başvurmasının nedeni, ifadeye üslup güzelliği vermek, anlaşılmasında güçlük çekilen konuları biraz daha anlaşılır kılmaya çalışmaktır. Mesnevîde konuların metaforlarla dile getirilmesi anlatıma bir zenginlik ve canlılık katmışır. Bu suretle konuya adeta yaşanılmış hissi verilerek gerçeğe uygunluk yakalanmaya çalışılmıştır (Çiçek 2003: 296).

Tasavvuf düşüncesi tarihinde, tasavvufi konuların anlamsız, bulanık ve belirsiz ifadelerden kurtarılıp, anlaşılır ve net bir şekilde ortaya konulması için metaforik ifadeler kullanılmıştır. Özellikle tasavvufí düşüncenin anlaşılmasındaki zorluklar düşünülürse, metafora duyulan gereksinim daha iyi anlaşılacaktır.

Bu çalışmada, "Acaba Mevlânâ, nefs kavramını açıklamak için hangi metaforları kullanmıştır?" temel sorusunun cevabı aranacaktır. Bu bağlamda, nefs kavramının Mevlânâ'nın zihin dünyasındaki yeri tespit edilmeye çalışılacaktır.

Çalışmada Mevlânâ'nın nefs kavramını açıklamak üzere kullandığı metaforlar insan tipleri, tarihî şahsiyetler, hayvan figürleri, eşya ve diğer motifler olmak üzere dört ana başlık altında ele alınmıştır. 


\section{A. İnsan Tipleri}

\section{Ana}

Mevlânâ, nefsi, mektebe gittiği için yorulan çocuğuna üzülen cahil bir anaya benzetir. Böyle bir ananın cahilce merhametinin çocuk için faydadan ziyade zarar vereceği aşikârdır. Mevlânâ şöyle der:

"O ana, çocuğun babasına; "Yavrucuğum mektepten bezdi, soldu, sarardı. Başka karından olsaydı ona bu kadar cefada bulunmazdın." der. Kendine gel, bu anadan ve onun merhametinden kaç. Babanın sillesi, onun helvasından yeğdir. Ana nefstir... Baba da cömert akıl." (1965: VI, 1433-7)'

Mevlânâ nefsin insana merhametli bir ana görünümünde yaklaşarak onu zararına olacak işlere yönlendirebileceğini anlatmaya çalışır. Kişinin nefsinin isteklerinden ve kendisine acıyormuşçasına verdiği iğvalardan kaçmasının gerekliliğini vurgular (Konuk 2008d: 473).

\section{Kötü Huylu Ana}

Mevlânâ, nefsinin kötülüğü sebebiyle başkalarına kötülük yapan bir insanın bu durumunu anlatmak üzere "kötü huylu ana" metaforunu da kullanır. Hikâye özetle şöyledir: Bir adam annesini öldürür. Niçin öldürdüğünü soranlara ise "Çok çirkin bir iş yaptı. Onun için öldürdüm.” der. "Ananı öldüreceğine o kişiyi öldürseydin ya." diyenlere ise: "Her gün başka birisini mi öldüreyim? Onu öldürdüm, halkın kanına girmekten kurtuldum; halkın boğazını keseceğime onu boğazladım, bu daha iyi!" cevabını verir. Mevlânâ hikâyeyi anlattıktan sonra şöyle der:

"O kötü huylu ana, fesadı her tarafta zahir olan nefsindir. Her an onun için bir azize kastedip duruyorsun; kendine gel, onu öldür! Onun yüzünden bu güzel dünya sana dar geliyor. Onun yüzünden Allah ile de savaşıyorsun, halkla da. Nefsini öldürürsen özür serdetmeden kurtulursun, ülkede hiçbir düşmanin olmaz." (Mevlânâ 1965: II, 779-782)

Dolayısıyla Mevlânâ, nefsi, kötü iş işleyen bir anaya benzetir. Bu ana var olduğu ve çirkin işlere devam ettiği sürece onun çocuğu nasıl ki her gün bir başkasına düşman olacaksa, tezkiye edilmemiş bir nefse sahip olan insan da bu nefsin kötü huyu sebebiyle her gün farklı bir insana kötülük yapacaktır. (Konuk 2008a: 220)

\footnotetext{
' Kaynak bilgisinde verilen son rakam beyit numarasıdır.
} 
Mevlânâ'ya göre insan nefsini tezkiye etmelidir ki o, ancak bu surette başkalarına kötülük yapmaktan kurtulabilsin.

\section{Kadın}

Mevlânâ, nefsin istek ve arzularını bir kadının kocasından istediği evin ihtiyaçlarına benzetir. Nasıl ki bir kadın evine lâzım olan şeyleri ister durursa, nefs de daima insandan isteklerde bulunur:

“Bu kadınla erkek, nefsle akıldır... Gece gündüz savaşta macera içinde. Kadın durmadan evin ihtiyaçlarını ister, evin şerefini, yani eve lâzım olan ekmeği, yüceliği, hürmeti diler durur. Nefs, kadın gibi her işe bir çare bulmak üzere gâh toprağa döşenir, tevazu gösterir; gâh ululuk diler, yücelir. Aklınsa, bu düşüncelerden zaten haberi yoktur. Fikrinde Allah gamından başka bir şey yoktur." (Mevlânâ 1965: l, 2617-2621)

Yine Mevlânâ nefsi hiçbir tedbiri olmayan cahil bir kadına benzetir. (Mevlevî 1976: IV, 1246; Konuk 2005: 202) Nefsin dediğini yapmanın insanı felakete düşüreceğini bu sebeple nefsin düşüncelerinin zıddına hareket edilmesi gerektiğini düşünür. (Konuk 2005: 296) Bu bağlamda o, hiçbir tedbiri, doğru düşüncesi ve bilgisi olmayan cahil bir kadınla istişare etmenin faydasızlı̆ını ifade eder. Şayet böyle bir kadınla istişare edilirse onun söylediği fikirlerin tam tersini yapmanın en doğru yol olacağını anlatır:

“Ümmet, 'Kiminle meşveret edelim?' dediler de, Peygamberler, 'Mukteda olan akılla.' diye cevap verdiler. Hatta soran adam 'Iyi ama ya hiçbir tedbiri, isabetli aklı olmayan bir çocuk, yahut kadın gelirse onunla da meşverette bulunalım mı?' deyince, Peygamber, 'Onunla da meşverette bulun, fakat ne derse onun zıddını yap, ona aykırı yola git.' dedi. Nefsini kadın bil, hatta kadından da beter... Nefsinle meşveret edersen o aşağılığın dediğine uyma, aksini yap; hatta sana namaz kll, oruç tut diye emretse bile, nefs hilecidir, o emriyle bile sana bir hile kuracaktır. Yapacağın işte nefsinle meşveret etmek ve ne derse aksini yapmak kemaldir." (1965: II, 2257-2263)

\section{Bey}

Mevlânâ, nefsin insanın aklına galip olma durumunu izah etmek için bey metaforunu kullanmıştır. Bir bey nasıl ki bulunduğu beldede hükümran olur, her dediği yerine getirilirse nefs de beden ülkesinde bey olur ve hükmünü icra etmeye başlarsa akıl bir esir hâlinde eli kolu bağlanmış olarak kalır. (Konuk 2007: 91) Aklını esir almış bir nefse sahip olan aptalın hâlini Mevlânâ şöyle dile getirir:

"Aptalın sevgisi şüphesiz ayının sevgidir... Onun nefsi beydir, aklı esir." (1965: 11, 2119-2125) 


\section{5. İnsana Pusu Kurmuş Düşman}

Mevlânâ nefsin insana düşman olduğu fikrindedir. O bu düşüncesini izah etmek için insana pusu kurmuş düşman metaforunu kullanarak şöyle der:

"içinde pusu kurmuş olan nefs ise, kibir ve kin bakımından bütün adamlardan beterdir." (1965: 1, 907)

Dolayısıyla Mevlânâ'ya göre insanın en büyük düşmanı içindeki nefsidir. Nefs, insanın içinde ona pusu kurmuş her an bir kötülük planlayan bir düşmandır. (Mevlevî 1976: 11, 516)

\section{Sofestai, Safsatacı}

Mevlânâ, nefsi, hiçbir ilmi delille ikna olmayan, her türlü delile demagoji ile karşılık veren, sadece laf kalabalığı yaparak hakkı kabulden imtina eden sofestai/safsatacıya benzetir. O bu metaforla nefsin hak karşısındaki inatçılığını ve dik başlılı̆ııı ifade etmek ister.

"Nefs Sofestai olmuştur, vur nefsin kafasına! Çünkü hakîkati kötekle anlar, delil getirmekle değil." (Mevlânâ 1965: 11, 3486)

Görüleceği üzere Mevlânâ'ya göre nefs, delille ikna olmayan bir tabiata sahiptir. Bu sebeple nefsi ikna için delil getirmek beyhude bir çaba olacaktır. Nefsin hakîkati anlayıp kabul etmesinin yegâne yolu riyâzettir. (Konuk 2007: 439-40)

\section{Hırsız}

Mevlânâ, kötülüklerinin önüne geçilebilmesi için nefsin cezalandırılması gerektiği düşüncesindedir. $\mathrm{O}$ bu düşüncesini izah etmek için hırsız metaforundan yararlanmıştır. Nasıl ki hırsızlığın toplumda yayılmaması ve insanların hırsızlığa cesaret edememesi için hırsızın eli kesilirse nefsin de kötülük yapamaması için eli tutulmalı ve ayağı bağlanmalıdır:

"Gerçekten de nefse arpa ekmeği bile haramdır. Nefsin önüne kepekle karışık ekmek koy. Tanrı yolunun düşmanını hor tut. Hirsızı minbere çıkarma, dara çek. Hırsızın elini kes. Kesmekten acizsen hiç olmazsa bağla. Sen, onun elini bağlamazsan $o$, senin elini bağlar. Sen, onun ayağını kırmazsan o, senin ayağını kırar." (Mevlânâ 1965: V, 3488-349ı)

Anlaşılacağı üzere Mevlânâ, hırsıza ikram edilip hürmet gösterilmemesi aksine onun horlanması ve cezalandırılmasından hareketle hırsıza benzettiği nefse de ikram edilmemesini ve onun kötülük yapamayacak bir hâle getirilmesini salık verir. (Konuk 2008c: 418-9)

\section{Sihirbaz}

Mevlânâ nefsin insanı aldatmak için hileler kurmasını ifade sadedinde onu sihirbaza benzetir. (Konuk 2007: 127) Sihirbaz nasıl ki yaptığı sihirle insanları 
hayrette bırakır ve etkisi altına alırsa nefs de istek ve arzuların cazibesini kullanarak insanı etkisi altına alır.

"Ben nefsimin hilesinden neler gördüm neler... O, sihriyle akıl ve temyizi bile giderir!.. O öyle bir sihirbazdır ki insanı kıskıvrak bağlar." (Mevlânâ, 1965: Il, 2266, 2269)

"Dünya sevgisi, dünya geçimine savaşma yüzünden sana o ebedî azabr ehemmiyetsiz gösterir. Ölümü bile ehemmiyetsiz bir hale getirirse bunda şaşlacak ne var ki? O, sihriyle bunun gibi yüzlerce iş yapar!.. işste senin içinde böyle bir sihirbaz gizlidir. Vesveselerde daimî bir sihir kudreti vardır!" (Mevlânâ, 1965: III, 4066-4067, 4072)

Dolayısıyla Mevlânâ'ya göre nefs, arzu ve isteklerini yerine getirmesi için insanı aldatan bir sihirbazdır. Nefsanî isteklerde bir sihir gücü vardır. Bu güç sayesinde nefs, insana bir çok çirkinlikleri güzel, bir çok güzellikleri de çirkin göstererek onu aldatmıştır. (Konuk 2006a: 440)

\section{9. Öküzü Öldürülen Davacı}

Mevlânâ nefs ile akıl arasındaki ilişkiyi açıklamak üzere efendisini öldürüp bütün malını gasp eden kölenin hikâyesini anlatır. Hikâye özetle şöyledir. Bir köle efendisini öldürüp tüm malını gasp etmiştir. Bu kölenin bir öküzü bir gün kaçarak bir eve girer. Ev sahibi de çok fakir bir kimse olup Allah'tan kendisine zahmetsiz bir rızık göndermesi için dua eden bir kimsedir. Fakir, Allah'ın kendisine bir rızık olarak bu öküzü gönderdiğini düşünerek hemen öküzü keser. Öküzün sahibi katil köle ise fakiri dava ederek öküzünü tazmin etmesini ister. Zamanın peygamberi Dâvûd (a.s.) ise Allah'tan aldığı vahiyle o fakir kimsenin, katil kölelin öldürdüğü efendinin oğlu olduğunu bilir. Bu sebeple de öküz karşılığında davacıya bir şey verilmemesi gerektiğine hükmeder. Ancak katil köle öküzün hakkını istemekte ısrarlıdır ve tüm halk da Dâvûd (a.s.)'ın bu hükmüne şaşmıştır. İşin neticesinde Dâvûd (a.s.) bütün hakîkati açıklar. Katil köle kısasen öldürülür. Bütün malı da efendinin oğluna verilir. Mevlânâ hikâyeyi şu şekilde açıklar:

"Nefsini öldür de âlemi dirilt. Nefs, efendisini öldürmüştür; sen, onu kendine kul, köle yap! Kendine gel, öküzü dava eden senin nefsindir; kendisini efendi yerine koymuştur, ululuk taslamaktadır. Öküzü öldüren de aklındır... Velinimetzade olan akıl, ihtiyaçlar içinde kalmış, kanlı katil nefs, efendi olmuş, öne geçmiş!." (1965: III, 2503-2505, 2509)

Görüleceği üzere Mevlânâ, nefsi, öküzü öldürülen fakat haksız olan davacıya; aklı da öküzü öldüren fakat haklı olan fakir davalıya benzetir. Aklın mahrumiyet içinde kalmasının sebebi, nefsin haksız yere efendi olması ve ululuk taslamasıdır. (Konuk 2006a: 33) Nefsin hakîkatinin anlaşılması ve onun terbiye edilmesi de ancak bir şeyhin yardımıyla gerçekleşebilir. 


\section{Riyâkâr Münâfik}

Mevlânâ, nefsin hilekârlı̆̆ını ve samîmîyetsizliğini riyâkâr bir münâfik metaforuyla açılar. Ona göre nefsin salâhına hiçbir zaman güvenilemez. Onun samîmî bir Müslüman gibi görünmesine aldanmamalıdır. Nefs, bu Müslüman görüntüsü altında yeninde hançer saklayan bir düşmandır:

"Nefsin yüz dili vardır, her dilinde ise yüz lügat. Onun hilesi ve riyası anlatılamaz ki!... Nefsin sağ elinde tespih ve Kur'an vardır ama yeninde de hançer ve kılıç gizlidir. Onun mushafina, onun riyasına kanma. Kendini onunla sırdaş, hâldeş yapma! Seni abdest al diye havuzun kenarna getirir de havuza, suyun ta dibine atıverir!" (Mevlânâ 1965: III, 2550, 2553-2555)

Dolayısıyla Mevlânâ'ya göre insan, nefsini terbiye ettiğini ve artık kendisine kötülük yapmayacak bir hâle kavuştuğunu asla iddia etmemelidir. (Konuk 2006a: 48) Çünkü nefsin bu teslim olmuş görüntüsü altında insana hazırladığı gizli bir hile ve düşmanlık bulunabilir. (Mevlevî 1976: X, 666)

\section{Atli}

Mevlânâ, nefsi, süvâriye benzetir. Bu süvârinin atı savaşta aldığı darbeler sonucu ölmüştür. Ancak süvâri ölmemiştir. Bedeni ata, nefsi süvâriye benzeten Mevlânâ, buradan hareketle, bedenle ruhun birbirinden ayrılması olarak nitelenen zahirî ölümün gerçek ölüm olmadığını, gerçek ölümün nefsin ölümü olduğunu izah eder:

“Doğruluk, can vermektir... Kur'an'dan "Erler vardır ki Allah ile ettikleri ahdi bozmadılar, ahitlerine doğrulukla sarıldılar." (Ahzâb, 33:23) ayetini okuyun! Madem ki bu beden, ruha bir âlettir, şu hâlde bu (ruhun bedenden ayrılması) hakîkî ölüm değildir. Nice ham kişiler vardır ki görünüşte kanlarını döktüler. Fakat nefsleri diri olarak o tarafa kaçtı. Aleti kırıldı ama yol kesen diri kaldı. Bindiği at kanlar saçtı ama nefs diri. At öldü, yolu aşılmadı. Ancak ham, kötü ve perişan bir halde kala kaldı. Her kanı dökülen şehit olsaydı öldürülen kâfir de kutlu bir şehit sayılırd." (1965: V, 3820-3825)

Mevlânâ, mezkûr ayette ifade edilen "sadâkat" kavramını can vermek olarak açıklar. Ancak onun "can vermek"ten kastı asla bilinen ölüm değildir. (Konuk 2008c: 509)O, bedeni, nefse ait bir âlet/binit olarak tasavvur eder. Bu yaklaşıma göre sadece bedenin ifnası, gerçek ölüm olmayacaktır. Çünkü bu durumda beden ölmüş ancak nefs diri olarak kalmıştır. Ona göre gerçek ölüm nefsin ölümüdür. (Demirci 2000) 


\section{Kâfir}

Mevlânâ nefse ihsanda bulunmanın yanlışlı̆̆ını ve ona cefa edilmesi gerekliliğini savunur. O bu düşüncesini açıklamak için nefsi, aşağılık ve kötü huylu bir kâfire benzetir:

"Aşağıllk, kötü kişilerin huyu budur. Sen ona iyilik ettin mi o, sana kötülük eder. Sabırla nefsin belini bük. $O$ alçaktır, kötüdür, iyilik etmeye gelmez ona! Kerem sahibi birisine ihsanda bulunursan değer. Bire karşıllk sana yedi yüz verir. Bu alçaga da cefa eder, onu kahreylersen sana aşır vefalar gösterir, kulun kölen olur. Kâfirler, nimete eriştiler mi cefa tohumunu ekerler de sonra cehennemde, aman yarabbi diye bağırıp $d u-$ rurlar... Alçaklar, cefaya, derde düștüler mi arınır, temizlenirler. Vefa gördüler mi de cefakâr olurlar. ... Vur alçakların başına ki yere baş koysunlar." (1965: III, 2977- 2982, 2993)

Anlaşılacağı üzere Mevlânâ, nefse iyilik etmenin onu daha da azgınlaştıracağını bu nedenle nefs terbiyesinde riyâzetin lüzumuna kanidir. (Konuk 2006a: 156)

\section{Kâfir Esir}

Mevlânâ insanın nefsine mağlup olma durumunu izah etmek üzere "eli bağlı kâfir esir" metaforunu kullanır. Hikâye özetle şöyledir: Bir sûfî, cihat sevabına nail olmak için savaşa katılır. Ancak savaş tekniklerini bilmediği için mücahitler onu geri hizmetlerde istihdam ederler. Sûfî, savaştan dönen gazilere, kendisinin de bir kâfiri öldürmek istediğini söyleyince gaziler, eli bağlı bir kâfir esiri öldürmesi için sûfîye izin verirler. Sûfî kâfiri öldürmek için yanına gidince onun bakışlarının sertliğinden korkup yere yığılır. Eli bağlı esir bu durumu fırsat bilerek onun boğazını ısırarak öldürmek ister. Duruma vakıf olan gaziler kâfiri derhal öldürür ve sûfîyi kurtarırlar.

"Sen de eli bağlı olan nefsinin elinde tıpkı o sûfi gibi alta düssmüss, kendinden geçmişsin. Yoldaki bir tepecikten aciz kalmışsın. Halbuki önünde yüz binlerce dağ var. Bu kadarcık bir tepeden korkup ölüye döndün, önünde aşılacak dağ gibi sarp yokuşlar var, nasıl gideceksin?" (Mevlânâ 1965: V, 3756-3759)

Mevlânâ nefsi eli bağlı kâfir esire, nefsine mağlup olan Müslüman'ı da eli bağlı esire mağlup olan sûfîye benzetir. $\mathrm{O}$, nefsin insanın aklı karşısında eli bağ $\iota_{\imath}$ bir esir konumunda bulunduğunu, insanın böyle bir düşman karşısında zaafa düşmesinin şaşılacak bir durum olduğunu düşünür. 


\section{B. Tarihî Şahsiyetler 1. Musa (a.s.)}

Mevlânâ, nefsi, insanın içinde bulunan bir iç düşman olarak tanımlar. Nefsinin isteklerini yerine getiren kişiyi kendi düşmanını besleyene benzetir. Bu düşüncesini açıklamak için “Hz. Musa (a.s.)" ve "Firavun” metaforlarını kullanır.

Firavun, kendisine düşman olacak bir çocuğu ortadan kaldırmak için binlerce masum çocuğu öldürmekteydi. Ama esas düşmanı olacak çocuk $\mathrm{Hz}$. Musa (a.s.) idi ve o Firavun'un sarayında nimetler içinde büyütülmekteydi. Bu tarihî hadiseden esinlenen Mevlânâ, insanın içinde bir iç düşman bulunduğunu fakat sahibinin bundan habersiz olarak başka insanlara savaş açtığını şu şekilde anlatır:

"Musa, onun evinde rahatça yaşadığı halde o, dışarıda beyhude yere çocukları öldürüp durmaktayd. Tenini besleyip yetiştiren; nefsine hizmet eden, sonra da başkalarının kendisine haset ettiğini, düşmanlıkta bulunduğunu sanan kişi gibi. "Bu, benim düsmanım, şu bana haset ediyor." der durur, halbuki kendisine haset eden, kendisine düşman olan o tendir, kendi nefsidir. ...Nefsi ten evinde nazla, naimle beslenmektedir, kendisi başkalarına kin güdüp elini ısırmakta." (1965: II, 768-772)

Mevlânâ, içindeki nefs düşmanından habersiz olan kişiyi, sarayındaki Musa (a.s.)'dan habersiz olan Firavun'a; nefsi de Firavun'un sarayında nimetler içinde büyütülen $\mathrm{Hz}$. Musa'ya benzetir. Firavun nasıl ki gerçek düşmanını beslediği halde masumlara düşmanlık ediyorsa, nefsinin isteklerini yerine getiren kimse de gerçek düşmanını bırakarak dışarıdaki masumlara düşmanlık etmektedir. (Konuk 2008a: 218-9)

\section{2. İsmail (a.s.)}

Mevlânâ, nefsin terbiye edilmesini kurban kesmekle özdeşleştirir. Ona göre nefsin başı kesilmelidir ki can/akıl mahvolmaktan kurtulabilsin. Nefsin terbiye edilmesini Hz. ibrahim (a.s.)'ın, oğlu Hz. İsmail (a.s.)'ı kurban etmesi hadisesine telmihle açıklar. Canı/aklı Hz. İbrahim (a.s.)'a, nefsi ise Hz. İsmail (a.s.)'a benzeten Mevlânâ şöyle der:

"Koyun keserken "Allahu ekber" dersin ya o geberesi nefsi keserken de bu söz söylenir. "Allahu ekber" de de o şom nefsin başını kes. Kes de can, mahvolmaktan kurtulsun. Ten ismail'e benzer, can Halil'e. Can bu semiz bedeni yatırdı da tekbir getirdi mi, ten kesilir, şehvetlerden hırslardan kurtulur, besmeleyle kesilmiş temiz bir kurban haline gelir." (1965: III, 2143-2145)

Anlaşılacağı üzere Mevlânâ'ya göre nefsin kurban edilmesi, onun terbiye edilmesi anlamına gelmektedir. Bir kurban kesilip ruhunu teslim edince nasıl ki 
$80^{* \text { TAED }} 48$

Adem ÇATAK

hiçbir nefsani isteği kalmazsa nefs de kurban edilmek suretiyle aşırı isteklerinden arındırılabilir. (Konuk 2008b: 567)

\section{Nemrut}

Nemrut, Hz. ibrahim (a.s.)'ı öldürmek için ateşe atmıştı. Allah'ın emri ile ateş Hz. İbrahim (a.s.)'ı yakmamıştı. Mevlânâ nefsi Nemrut'a, aklı da Hz. İbrahim (a.s.)'a benzetir. Ona göre terbiye olmamış nefsin ateşten/cehennemden korkması gerekir. (Konuk 2007: 392) Ateşten kurtulmak için nefsin akla tabi olması ve fitratındaki kötülükleri iyiliklere tebdil etmesi gerekmektedir.

"Ateş, ibrahim'e bir ziyan veremedi. Kim Nemrutsa sen ona de: "Kork ateşten!" Nefs Nemrut'tur, akılla can da Halil." (Mevlânâ 1965: 11, 3296-3297)

\section{4. Şeytan}

Mevlânâ, nefsin Hakk'ın emirlerine itaatten yüz çevirmedeki inadını anlatmak için "şeytan" metaforundan yararlanmıştır. Allah, şeytandan $\mathrm{Hz}$. Adem (a.s.)'a secde etmesini istemiş fakat o bu emre itaat etmemişti. Şeytan, bu isyanında inat etmiş ve neticede ilahî huzurdan kovulmuştu. (Bakara 2:34) Mevlânâ nefsin şeytanla aynı tabiatta oluşunu ve inatta ona benzeyişini şöyle açılar:

"Nefsle şeytan, ikisi de birdir... surette kendisini iki gösterdi... Hikmeti var da onun için iki suret oldu. Senin içinde, akI alan, cana da düsman, dine de düsman olan böyle bir düssmamın var... Hadisteki șu güzel öğüdü duy; 'Düssmanlarınızın en kuvvetlisi, içinizdedir!' (Beyhakî 1996: 156) Bu düşmanın palavrasını dinleme, kaç ondan... Çünkü o da inatta iblis'e benzer." (1965: III, 4051-4053, 4065)

Mevlânâ, insana kötülük yapma hususunda nefs ile şeytanın aslında bir olduklarını düşünür. (Konuk 2006a: 435) Ona göre, insanın içinde ona kötülük etmek için firsat kollayan nefs, Hakk'ın emirlerini yerine getirmede iblis gibi inat eder. Mesnevî şârihi Mevlevî, nefsin dahilî bir düşman olması yönüyle haricî düşman olan şeytandan daha şiddetli bir düşman olduğunu ifade eder. (Mevlevî 1967: Xl, 1055)

\section{Sebeliler}

Mevlânâ nefsin, Rabb'ine karşı nankörlüğünü anlatmak üzere "Sebeliler"i örnek verir. Sebeliler'in kendilerine verilen nimetlere nankörlük ettiklerini bu sebeple de tüm nimetlerin ellerinden alındığını (Sebe', 34:15-19) anlatan Mevlânâ nefsin de Sebeliler gibi nankör olduğunu bundan dolayı da Allah'ın "Nefslerinizi öldürün...” (Bakara 2:54) emrine muhatap kaldı̆̆ını izah eder.

"Sebeliler, heveslerine uymuş ham kişilerdi. işleri, güçleri büyüklerin nimetlerine karşı nankörlükte bulunmaktı. Sebeliler 'Şehirlerimiz birbirine çok yakın, onları uzaklaştır. Kötülük, çir- 
kinlik bize daha iyi, bizim ziynetimizi güzelliğimizi al. Biz, bu köskleri, bağları, bahçeleri istemiyoruz...' dediler... Insan yazın kışı ister, fakat kış geldi mi bundan da vazgeçer, istemez. Bir hâle katiyen razı olmaz. Ne darlıktan hoşlanır, ne genişlikten, bolluktan. Geberesi insan, efendisine ne de kâfirdir ya... Hidayete nail oldu mu tutar, inkara sapar... Nefs, bu çeşit mahluklardandır da onun için gebertilmeye layıktır... Onun için ulu Allah “Öldürün nefslerinizi." demiştir." (Mevlânâ 1965: III, 364-374)

Dolayısıyla Mevlânâ, nefsin, verilen nimetlere şükretmesi gerekirken aksine nankörlük yapma eğiliminde olduğunu düşünür. (Mevlevî 1967: IX, 96) Nefsi, nankörlük hasleti yönünden Sebeliler'e benzeten Mevlânâ, Sebeliler'in Allah tarafından cezalandırılmalarından hareketle nankör olan nefsin de cezalandırılması gerektiğini ifade eder. (Konuk 2008b: 113)

\section{Hayvan Figürleri}

\section{Aslan}

Mevlânâ nefsin gücünü ifade etmek için "aslan" metaforunu kullanır. Aslan, yırtıcılıkta ve diğer hayvanlara üstünlükte bir sembol hâline gelmiştir. (Yaylagül 2010: 116) Mevlânâ nefsin gücünün basite alınmaması gerektiğini salık verir. (Konuk 2009a: 416) Ona göre zahiri düşman karşısında üstün gelmek, insanın içindeki düşman karşısında üstün gelmesinden kolaydır:

"Ey padişahlar! Dışarıdaki düşmanı öldürdük; içimizde ondan beter bir hasım var. Bunu öldürmek, aklın fikrin işi değil. içerideki aslan, öyle tavşan maskarası olmaz." (Mevlânâ 1965: 1, 1374-1375)

Görüldüğü üzere nefsi aslana benzeten Mevlânâ, insanın içindeki düşmana galip gelmesinin, aslanla savaşarak onu öldürmek kadar zor bir durum olduğunu ifade eder. (Durak 2006)

Nefsin ancak aşk ile öldürülebileceğini ve aşkın da Allah'ın bir tevfiki olduğunu söyleyerek bu beyitleri şerh eden Tahiru'l-Mevlevî, nefse mukabil akıl ve idrakin, yırtıcı aslan karşısında aciz bir tavşan gibi kalacağını anlatır. (Mevlevî 1976: 111, 721)

\section{2. Öküz}

Mevlânâ nefsin kanaatsizliğini ve Allah'a itimadının azlığını izah etmek için "öküz" metaforunu kullanır. Hikâye özetle şöyledir: Büyük bir adada yaşamakta olan bir öküz Allah'ın kendisine ikram ettiği ot, çayır ve çimenle beslenirdi. Her gün akşama kadar adada ne kadar ot varsa hepsini yer ve şişmanlar fakat gece olunca "Bütün ovayı otladım, hepsini bitirdim. Yarın ne yiyeceğim?" diye korkuya ve derde kapılır, sabaha kadar gözüne uyku girmez ve bu dertle zayıflardı. Sabahleyin kalkınca yine bütün yazıyı, dünkünden daha yeşil, daha bol çayır ve 
$\underline{82^{*} \text { TAED }} 48$ Adem ÇATAK

çimenle dolu bulur, yine yer, içer, semirir, gece olunca da yine aynı derde düşerdi. Yıllardır bunu görür, fakat Tanrı'ya yine güvenmezdi.

"İşte nefs, o öküzdür, yazı (ada) da dünya. Nefs, ekmek korkusu ile daima zayıflar durur. 'Gelecek zamanlarda ne yiyeceğim? Yarının rızkını nasıl ve nerede elde edeceğim?' kaydına düşer. Yıllardır yedin, yiyeceğin eksilmedi... Yediğin rızıkları hatırına getir, geleceğe bakma da az sızlan!" (Mevlânâ 1965: V, 2866-2869)

Anlaşılacağı üzere Mevlânâ, insanın tensel kaygılarının merkezi konumunda olan nefsi, hayatı boyunca rızkı verildiği ve hiçbir gün aç bırakılmadığı hâlde yine de rızlk endişesine düşen öküze benzetir. (Ögke 2009: 13) Bu noktada o aslında tüm mahlukatın rızkının Allah Teâlâ tarafından teminat altına alınmış olmasına (Hûd, 11:6) rağmen Allah'a itimat edemeyen insanı eleştirmektedir. (Konuk 2008c: 244)

Mevlânâ, Mesnevînin bir başka yerinde manevi dirilişe ulaşılabilmenin nefsin terbiye edilmesine bağlı olduğu düşüncesini "boğazlanan öküz" metaforuyla açıklar. Mevlânâ, Hz. Musa (a.s.) zamanında gerçekleşen bir katl olayının aydınlatılması için bir ineğin boğazlanarak maktule vurulması ve bu suretle maktulün dirilerek kendisini öldürenleri haber vermesi olayını (Bakara 2: 67-74) anlatır:

“O öldürülmüş adam öküz kuyruğu kamçısının açtı̆̆ yaradan dirildi... Sıçrayıp kalktı, sırları söyledi, kanını dökenleri gösterdi... Bu ağır beden de öldürüldü mü sırları bilen ruh varliğı dirilir. $O$ adamın canı cenneti de görür, cehennemi de. Bütün sırları da tanır, bilir... Kuyruğunun açacağı yara yüzünden can kurtulsun diye öküz kesmek, yol şartlarındandır. Sen de tez öküz nefsi tepele de gizli ruh dirilsin, akıllansın." (Mevlânâ 1965: II, 1431-1438)

Mevlânâ, öküzün öldürülmesi ve kuyruğuyla ölüye vurulması neticesinde maktulün dirilmesinden hareketle nefsin öldürülmesi sonucu insanın manevi bir dirilik kazanacağını düşünür. (Konuk 2008a: 402)

Ona göre "Öküz kesmek" nefsi eğitmek, yenmek ve alt etmek demektir. "Öküz kesmek yol şartlarındandır" derken Mevlânâ, nefs terbiyesi yoluyla onun her türlü kötülük, kabalık ve çirkinliklerinin giderilmesinin tasavvufun temel esasları arasında yer aldığını metaforik bir dille belirtmek istemiştir. (Ögke 2009: 14)

\section{Köpek}

Mevlânâ nefsi bir av köpeğine benzetir. Av köpeği avcının yanında ona yardım etmek üzere ava gider. Av köpeğinin avcıya yardım edebilmesi için bakımlarının güzel yapılmış olması gerekir. Hasta ve zayıf/aç bir av köpeğinin kendisinden istenilen vazifeyi hakkıyla deruhte edemeyeceği izahtan varestedir. Bununla birlikte Mevlânâ, köpeğin aşırı beslenmesi ve şımartılmasının onu serkeşli- 
ğe sürükleyeceğini ve bu nedenle de avcının istediği yardımı yapmayacağını da ifade eder. (Mevlevî 1976: V, 1353) İnsan da Rabb'ine giden yolda nefsinin kendisine yardımcı olduğunu bilmeli ve onun haklarını gözetmelidir. (Konuk 2005: 273-4) Ancak nefsin her türlü isteğini yerine getirmenin yanlış olduğu da bilinmelidir.

“Acıkınca kızgın, geçimsiz, aslı kötü bir köpek oluyorsun. Karnın doyunca murdarlaşıyor, ayak üstünde duran ve hiçbir şeyden haberi olmayan bir duvar kesiliyorsun. Şu hâlde sen bir zaman pis ve murdar bir hâle geliyor, bir zaman köpekleşiyorsun. Sana yarayan köpek, ancak avlanmakta kullanacağın köpektir. Bunu böyle bil de köpeğe daha az miktarda kemik at. Çünkü köpeğin karnı doyarsa daha ziyade serkeşleşir. Bu serkeşlikle o köpek istediğin gibi ava gider mi?" (Mevlânâ 1965: l, 28732876)

Görüleceği üzere Mevlânâ, nefsi bir köpeğe benzeterek terbiye edilse bile tabiatı icabı her an tekrar kötülüğe dönme huyuna sahip olduğundan daima kontrol edilmesi gerektiğini düşünmektedir. Ona göre nefse değer verilmemeli ve nefs aşağılanmalıdır.

"Yol güneşi olan Hz. Peygamber (s.) bile: Nefsini aşağılayan kişiye ne mutlu' dedi. Ey yoksul, bunun için diyorum işte. Köpeğin boynundan tasmayı çözme. Bu köpek terbiye edilse bile yine köpektir. 'Ne mutlu nefsini așağılayana.' hükmüne uy. $O$ (nefs) kötü damarlıdır. (Kötü huyludur.)" (Mevlânâ 1965: IV, 3344)

Mevlânâ, nefsi ayrıca kendi yurdunda yaşayan bir köpeğe, aklı da yurdundan uzak kalmış bir garibe benzeterek şöyle der:

"Akıl, nuranî ve iyi bir hak ve hakikat arayıcısıyken neden zulmanî nefs ona galip oluyor? Neden mi? Nefs, kendi evinde, kendi yurdunda, akılsa garip! Köpek bile kapısında korkunç bir aslan kesilir! Hele sabret, aslanlar ormana gelsinler. Bu kör köpekler, o vakit onlara tabi olurlar." (1965: III, 2556-2558)

Anlaşılacağı üzere Mevlânâya göre beden, nefsin yurdu, nefs de bu yurtta hükmünü sürdüren köpektir. En korkak bir köpek bile kendi evinde nasıl cesaretli bir aslan kesilirse bunun gibi nefs de bu beden yurdunda hükmünü yürütmede cesaret bulur. (Mevlevî 1976: X, 667) Akıl ise ruhlar âleminden olmakla (Konuk 2005: 204) bu bedenden ve bedeni özelliklerden habersiz ve ilgisiz (Mevlânâ 1965: 1, 2620-2621) olmakla yurdundan uzak düşen bir garip durumundadır. (Konuk 2006a: 48)

Mevlânâ, nefsi tanımlamak için Mesnevînin bir başka yerinde de yine köpek imajına başvurur: 
"Sen de kendine gel, köpek nefsini diriltmeyi isteme. Çünkü o nice zamandır senin düşmanındır." (1965: 11, 472)

\section{Eşek}

Mevlânâ, nefsin her an dizginlenmesi gerektiğini ve ondan asla gafil olunmaması gerektiğini düşünür. Bu düşüncesini izah etmek üzere "eşek" metaforunu kullanır.

"Eşeğin başını çek, onu yola sok, doğru yolu bilen ve görenlerin yoluna sür. Onu boş bırakma, yularını tut; çünkü o, yeşilliğe gitmeği sever. Gaflet edip de bir an boş bıraktın mı çayırlara doğru fersahlarca yol alır. Eşek yol düşmanıdır, yeşillik görünce sarhoş olur." (Mevlânâ 1965: I, 2950-2953)

Mevlânâ, eşek metaforuyla insanın nefsini, yeşillik/çayırlık metaforuyla da nefsanî zevkleri anlatmak istemiştir. (Mevlevî 1976: V, 1385) Ona göre nefs her an isteklerine yönelme eğilimindedir. (Konuk 2005: 295)

Mevlânâ, insanın yapacağı işlerde doğruyu seçememesi durumunda nefsanî isteklerinin zıddını tercih etmesinin doğruyu bulmada makbul bir yöntem olacağını düşünür. (Mevlevî 1976: V, 1386; Konuk 2005: 295) O bu düşüncesini izah etmek için de yine eşek metaforundan yararlanır.

"Eğer yol bilmezsen eşeğin dileğine aykırı hareket et; doğru yol, o aykırı yoldur." (Mevlânâ 1965: 1, 2954)

Mevlânâ nefsî isteklerin değil aklın gereklerinin yerine getirilmesinin doğru bir iş olduğunu " $\mathrm{Hz}$. İsa" ve "eşek" metaforlarıyla anlatarak şunları söyler:

"Fakat sen, isa'yı bıraktın da eşeği besledin. Hulasa eşek gibi perdenin ardında kaldın gitti! Bilgi ve irfan, Isa'nın talihidir, ey eşek sıfath, eşeğin talihi değil! Eşeğin anırmasını duyar, acırsin. Halbuki bilmezsin ki eşek, sana eşeklik telkin ediyor. Isa'ya acı, eşeğe değil. Tabiatı aklına baş etme. Bırak tabiatını, ağlaya dursun. Sen, ondan al, canın borcunu öde! Yeter artık yıllarca eşeğe kul oldun. Çünkü eşeğe kul olan, eşeğin ardından gider... Nefs geride, aklin ilerde gerek." (1965: II, 1840-1846)

Mevlânâ, nefse hakim olmanın gerekli olduğunu ifade etmek için "çıplak/semersiz eşek" metaforunu da kullanmıştır:

"Ey boşboğaz, eşeğe çıplak bin. Peygamber, çıplak binmedi mi? 'Peygamber, çıplak eşeğe bindi. Yaya yürüdü de.' denmiştir. (Müslim 1332: 40, 116) Eşek nefsin kaçıyor, onu bir kazığa bağla. Ne zamana kadar işten, yükten kaçacak? Ister yüz yıl olsun, ister otuz yıl, mutlaka sabır ve şükür yükünü yüklemeli." (Mevlânâ 1965: II, 724-727)

Mevlânâ bu hadisi tasavvufi bir bakış açısıyla yorumlayarak kişinin nefsine hiç taviz vermeden hakimiyeti altına alması gerektiği sonucuna varmıştır. 
Mevlânâ, hadis-i şerifte geçen "Hz. Peygamber çıplak eşeğe bindi." ifadesindeki "eşek"i nefs olarak anlar ve "sen de nefsine bin ve onu çıplak eşek gibi kendi işinde kullan, ona her an hakim ol, sen onun isteklerine değil o senin isteklerine bağlı olsun." demek istemiştir. Eşeğin "çıplak" olması "semersiz" oluşu anlamındadır. Bu durumda "eşeğe çıplak binilmesi" nefsle mücadelede kararlı ve cesaretli olunması olarak açıklanabilir. (Konuk 2008a: 205)

Nefsi, "yükten kaçan eşeğe" benzeten Mevlânâ, onu terbiye etme yollarından biri olan "sırtına sabır ve şükür yükünü yükleme"yi de salık vermektedir. (Ögke 2007: 26)

Mevlânâ nefsin terbiye edilmesinde mürşidin rolünü anlatmak için "tuzlaya düşmüş eşek" metaforundan yararlanır. $\mathrm{O}$, nefsi arındırabilmenin en kolay yolunun bir mürşidin terbiyesine girmek olduğunu savunur.

"Ölmüş eşek tuzlaya düşünce eşekliği, murdarlı̆ğ bir tarafta kalır." (Mevlânâ 1965: 11, 1336)

Mevlânâ'nın bu beytinde "ölmüş eşek" metaforuyla hakîkat bilgisinden habersiz, manen ölü nefs, "tuzla" metaforuyla ise insanı hevâ ve heveslerinden arındırarak nefsini tezkiye etmesine yardım eden mürşid simgelenmiştir. (Konuk 2008a: 375)

Mevlânâ nefsin istekleri uğruna can vermenin çirkinliği ifade etmek için "eşek altına düşmek" metaforunu kullanır.

"Kötü ölüm, yüzlerce rezillikle gelip çattı babacığım... Bil ki bu hayvan nefs, bir erkek eșektir. Onun altına düssmekse ondan daha kötü ve ayıp bir şeydir. Nefs yolunda benlikle ölürsen bil ki hakîkatte sen de o (eşek altına düşen) kadın gibisin. Tanrl, nefsimize eşek sureti vermiştir... Tanrı hakkı için eşeğe benzeyen nefsten kaç." (Mevlânâ 1965: V, 1390-1395)

Görüleceği üzere nefsi eşeğe benzeten Mevlânâ, nefsanî istekler peşinde koşan ve bu uğurda hayatını kaybeden insanı da eşek altına düşmüş bir kadına benzetir. (Konuk 2009c: 460; Ögke 2007: 26-28)

\section{Ejderha}

Mevlânâ nefsin gücünü ve insana verebileceği zararları anlatmak üzere "ejderha" (Günay 1983: 36-37; Köksel 2009: 464-478; Altınkaynak 2003: 21-23) metaforunu kullanır. Mesnevîde anlatılan hikâye özetle şöyledir: Bir avcı kış mevsiminde ava çıkar. Ormanda büyük bir yılanı/ejderhayı kış uykusuna yatmış hâlde bulur. Ejderhayı iplerle bağlayarak Bağdat şehrine getirir. Yılanı insanlara teşhir ederek hem kahramanlığılla övünmek hem de yılanı seyretmeye gelenlerden para kazanmak ister. Bağdat'in güneşi altında uzun süre bekleyen yılan kendisine gelerek başta avcı olmak üzere etrafındaki insanlardan bir çoğunu öldürür.

Mevlânâ, hikâyeyi anlattıktan sonra, 
"Senin nefsin de bir ejderhadır. $O$, nereden öldü ki? Dertten, eline firsat düssmediğinden dondu, yoksa!... O ejderha, yoksulluk elinde bir kurtcağız kesilir... Ejderhayı ayrılık karı içinde tut, sakın onu Irak güneşinin altına getirme. Ejderhan donmuş bir hâlde iken selamettesin fakat kurtuldu, kendine geldi mi ona lokma olursun." (1965: III, 1053-1058) der.

Mevlânâ "donmuş ejderha" metaforuyla ham sûfînin terbiye ettiği zannına kapıldığı nefsini betimler. Ham sûfi, yapmış olduğu bir takım riyâzet, zikir, tefekkür vb. neticesinde nefsini tezkiye ettiğini sanır. Nefsine tam manasıyla hakim olduğunu düşünür. Aslında nefsi hâlâ diri ve onu kötülüklere sürükleyebilecek kadar güçlüdür. Ancak nefs, eline firsat geçmediğinden terbiye olmuş hâline bürünür. (Konuk 2008b: 281) Nefsin eline firsat geçmesi durumunda yapamayacağı kötülük ve zulüm yoktur. (Mevlevî 1976: IX, 268-269)

Mevlânâ donmuş ejderha metaforuyla aynı anlamda olmak üzere "kuyuya hapsedilmiş ejderha" (Günay 1983: 40) metaforunu da kullanır:

"Firavunda olan yok mu? Sende de var. Fakat senin ejderha kuyuya hapsedilmiş! Yazıklar olsun, bunların hepsi de senin ahvalin. Fakat sen, onları Firavun'a isnat etmek istersin... Senin ateşine, Firavun'un ateşine atılan odun atılmamakta, onun gibi firsat bulamiyorsun sen. Yoksa firsat bulsan senin ateşin de Firavun'un ateşi gibi yalımlanır!" (Mevlânâ 1965: III, 971-975)

Görüldüğü üzere Mevlânâ Firavun'un nefsinin "açık alanda" olduğu için bir çok kötülükleri yapmaya güç yetirebildiğini ancak diğer insanların nefslerinin "kuyuda hapsedilmiş" olduğundan kötülük yapamadığını izah eder. (Konuk 2008b: 263) Burada ejderhanın açık alanda olması insanın elinde mal, makam ve güç bulunması anlamında iken, ejderhanın kuyuda hapsedilmiş olması ise insanın fakirlik, zayıflık, hastalık vb. gibi güçsüzlük durumunda bulunduğu anlatılmak istenmiştir. (Mevlevî 1976: IX, 244)

Mevlânâ, ejderha olan nefsin, ancak bir mürşidin terbiyesiyle etkisiz hale getirilebileceğini düşünür.

"Nefs, yüzlerce hile, hud'a sahibi bir ejderhadır. Fakat şeyhin yüzü, o ejderhanın gözüne karşı tutulan bir zümrüttür." (Mevlânâ 1965: 111, 2547)

Anlaşılacağı üzere Mevlânâ nefsi ejderhaya, şeyhi de ejderhanın gözüne tutulan zümrüde benzetir. (Konuk 2006a: 46) İnanışa göre bir yılanın gözüne zümrüt tutulursa yılanın gözü kör olur veya akar. (Çubukçu 1985: 90) Mevlânâ halk arasında dolaşan bu mitolojik anlatımı nefs ve mürşid ilişkisini açıklamak üzere anlatmıştır. Nasıl ki zümrütten çıkan şualar yılanın gözünü kör ediyorsa bir mürşidin kalbinden akseden ilahî nurlar ve feyizler de insanın nefsinin gayr-i meşru isteklerini yok eder. 


\section{Sivrisinek, Atmaca, Kurtçuk}

Mevlânâ nefsin eline firsat geçince her türlü kötülüğü yapabilecek bir tabiatta olduğunu anlatmak için "atmaca" (Armutak 2004: 149-150) ve "sivrisinek" metaforlarından yararlanır.

"Onun eline de böyle bir kudret düssse hemen firavunluğa başlar, yüzlerce Musa'nın da yolunu vurur, yüzlerce Harun'un da! ... Mevki ve mal yüzünden bir sivrisinek büyür, atmaca kesilir!" (Mevlânâ 1965: III, 1055-1056)

Sivrisinek zayıflı̆̆ sembolize eden bir metafordur. (Çetinkaya 2011: 44) Mevlânâ'ya göre nefs elinde firsat ve imkan olmadığında bir sivrisinek kadar güçsüzdür. Ancak güce ve imkana kavuşunca yırtıcı bir kuş olan atmacaya döner. Artık ondan her türlü kötülük beklenir. (Konuk 2008b: 28I)

Yine Mevlânâ aslında ejderha olan nefsin yoksulluk, hastalık vb. güçsüzlükler sebebiyle bir kurtçuğa döneceğini de ifade eder. 1056)

“O ejderha, yoksulluk yüzünden bir kurtcağız kesilir." (Mevlânâ 1965: III,

\section{Yarasa}

Mevlânâ nefsin isteklerinin karşılanmasının onu teskin etmek yerine daha fazla azdıracağını düşünür. İstekleri yerine getirilmiş nefsi üzerine güneş vurmuş yarasaya (Armutak 2004: 149; Şimşek 2008: 408) benzetir. Nasıl ki bir yarasa güneşe tahammül edemez hemen harekete geçerse nefs de istekleri yerine gelince hemen harekete geçer ve sahibini kötülüklere sevk eder. (Konuk 2008b: 283)

"Üstüne şehvet güneşi vurdu mu o geberesice nefs hemen yarasa gibi kanatlarını çırpmaya, uçmaya başlar. Ercesine onu savaşa çek, babayiğitçe onunla vuruş." (Mevlânâ 1965: III, 1060-106ı)

\section{Fare}

Mevlânâ, nefsin sınırlılığını göstermek ve onu küçümsemek için "fare" metaforunu kullanır. Bununla nefsin sadece dünyayı istediğini, bedensel zevkler peşinde koştuğunu ve onun büyük idealleri düşünecek kapasitesi olmadığını anlatmak ister:

"Kısa görüşlü, daima halden hale giren, renkten renge boyanan ve temkini bulunmayan, kişiye 'fare' dedim, çünkü yeri, yurdu topraktır. Farenin de geçim yeri topraktan ibarettir. Yolları, izleri bilmez değil, bilir ama yer altındakileri bilir. $O$, her yanda toprağı delmiş, delik deşik etmiştir. Fare gibi nefs, ancak lokma ufalar. Allah fareye de miktarınca akıl vermiştir. Çünkü yüce Allah, hiç kimseye, ihtiyacından artık bir şey vermez." (1965: II, 3256-3260) 
Dolayısıyla Mevlânâ "fare" ile nefsi, "farenin toprak yurdu" ile de bu dünyayı betimlemiştir. (Konuk 2007: 380) Ona göre dünya topraktan ibarettir. Dünyevî zevkler de toprağın değişik bir formudur. (Mevlânâ 2008: 173)

Yine Mevlânâ, Allah'ın fareye, sadece kendisine yetecek kadar akıl verdiğinden hareketle insanın akl-ı maaşını izah eder. İnsanda bulunan akl-ı maaş onun dünyevî işlerini tedbire yetecek kadardır. (Mevlevî 1976: 8, 971) Akl-ı maaş sadece bu dünya işleri ile sınırlı bir alanda görev icra edebilir. (Mevlânâ 1994: 200)

$\mathrm{O}$, "toprakta yurt tutan fare" metaforuyla bedendeki nefsi de anlatır. Çünkü ona göre bu bedende ruh yoksa o da topraktan ibarettir:

"Bir gönülde gönül nuru olmadı mı o gönül gönül değildir. Bir bedende ruh yoksa o beden topraktan ibarettir." (Mevlânâ 1965: V, 2878)

\section{Tavşan}

Mevlânâ, insanın tüm kudret ve üstünlügüne rağmen nefsine mağlup olmasını bir tavşan (Armutak 2004: 150) tarafından kuyuya atılan aslan metaforuyla tasvir eder.

"Tavşan, aslanı zindana soktu. Aslan için ne ayıp şey; bir tavşancıktan geri kaldı!... Ey kişi! Sen, bu dünya kuyusunun dibinde mahpus kalan bir aslansın. Tavşan gibi olan nefsin, seni nasıl kahretti? Senin tavşan nefsin sahrada yiyip içmekte, zevk ve sefa etmekte. Sen ise şu dedikodu, bahis ve münakaşa kuyusunun dibindesin! " (Mevlânâ 1965: I, 1350-1353)

Görüleceği üzere Mevlânâ, bu beyitlerinde nefsi tavşana, insanı ise akıl ve ilahî ruh gibi sahip olduğu değerler bütünü olarak aslana benzetir. (Konuk 2005: 411) Ona göre bir aslanın tavşana mağlup olması nasıl şaşılacak bir durumsa insanın nefsine mağlup olması da o denli garipsenecek bir durumdur. (Mevlevî 1976: 111, 711)

\section{Fil}

Mevlânâ, nefsi "fil"e benzetir. Bunu bir hikâyesinde genişçe anlatır ki özetle şöyledir: Bir ormandaki su kaynağına gelen fil sürüsü orada yaşamakta olan tavşanları rahatsız eder. Tavşanlar, filleri su kaynağından uzaklaştırmak için bir hileye baş vururlar. Lider tavşan bir gece fillere doğru seslenerek, kendisinin ayın elçisi olduğunu söyler. Su kaynağının sahibinin ay olduğunu ve ayın fillerin su kaynă̆ını terk etmelerini istediğini anlatır. Delil olarak da dolunay gecesinde suyun titremesini gösterir. Fillerin lideri dolunay gecesi suya gider ve hortumunu suya sokunca su dalgalanır. Filler tavşanın sözüne inanırlar ve bölgeyi terk ederler.

"A herzevekil, o tavşanın hakîkati şeytandır. Senin nefsine elçi olarak geldi de, ahmak nefsini, Hızır'ın içtiği âb-ı hayattan mahrum etti." (Mevlânâ 1965: III, 2805-2806) 
Mevlânâ, bu beyitlerinde insanı aldatmak üzere vesvese veren şeytanı "tavşan”a, şeytanın vesvesesine uyarak Peygamberlerin tebliğine olumsuz cevap veren insanların nefsini de "fil"e benzetir. (Konuk 2006a: 114) Filin tavşanın deliline inanarak sözlerinin doğruluğunu kabul etmesi, nefsin şeytanın delillerine inanarak onun vesvesesine kapılmasına benzer.

\section{Karga}

Mevlânâ, nefsin isteklerinin peşinden gidilmemesi gerektiğini anlatmak üzere "karga" metaforundan yararlanmıştır. Habil'i öldüren Kabil'in kardeşinin cesedini defin işlemini bir kargadan öğrenmesinden (Mâide 5:31) hareketle Mevlânâ, insanın kargaya benzeyen nefsî isteklerin peşinden gitmesinin yanlışlığını şu şekilde vurgular:

"Karga, ardınca uçan canı nihayet mezarliğa götürür! Kendine gel de kargaya benzeyen nefsin ardından koşma...çünkü o, seni mezarliğa götürür, bağa, bahçeye değil!... Eğer gideceksen gönül Anka'sının ardından git...Kaf dağına, gönül Mescid-i Aksâ'sına var!" (1965: IV, 1310-1312)

Bu beyitlerinden de anlaşılacağı üzere o, "karga" metaforuyla (Özbaş 2010: 57-65) nefsi, "mezarlık" metaforuyla da cehennemi özdeşleştirir. (Konuk 2006b: 378) Ona göre nefsî istekler peşinde koşmanın doğal sonucu dünya ve ahirette bedbahtlıktır.

\section{Mecnûnun Devesi}

Mevlânâ, nefs ile aklın birbirine aykırı mizaçlara sahip olduğunu, nefse tabi olunarak ulvi makamlara ve sevgilinin vuslatına ulaşılamayacağını izah etmek için Leylâ'nın diyarına gitmek isteyen Mecnûn'un hikâyesini anlatır. Hikâye özetle şöyledir: Mecnûn, sevgilisinin diyarına gitmek üzere devesine biner. Fakat devenin yavrusu vardır ve deve yavrusundan ayrılmak istememektedir. Mecnûn devesini zorla Leylâ'nın diyarına doğru yola koşar. Bir müddet yol alınca Mecnûn deve üzerinde uyur. Devesi ise bunu firsat bilerek geriye döner ve yavrusunun bulunduğu şehre doğru yol almaya başlar. Mecnûn uyanınca devesini tekrar Leylâ'nın memleketine çevirir. Bu olay birkaç kez tekerrür edince Mecnûn deveden iner ve yoluna yürüyerek devam eder:

“Bu, Mecnûn'la devesine benzer. O, ileriye gitmeye savaşır, bu geriye gitmeye! Mecnûn'un sevdası, önde bulunan Leylâya kavuşmak, devenin sevdası ardına dönüp yavrusuna ulaşmak! Mecnûn, bir an bile kendisinden geçti mi deve, hemencecik geri döner, geriye giderdi... Nihayet dedi ki: 'A deve, ikimiz de aşı̆̆ız ama birbirimize aykırıyız. Arkadaşlığa layık değiliz! Senin sevgin de bana uygun değil, yuların da. Senden ayrılmak gerek!" (Mevlânâ, 1965: IV, 1532-1542) 
Görüldüğü üzere Mevlânâ'ya göre, ulvi makamlara ulaşmak isteyen insan, yol almasına engel olan nefsinden kurtulmalıdır. (Soysaldı 2007: 165) Çünkü nefs ile aklın ulaşmak istediği maksat farklıdır. (Mevlevî 1976: XIl, 401-403; Konuk 2006b: 449) Nefsinden kurtulamayan insanın durumunu ise Mevlânâ,

"Bu iki arkadaş da, birbirinin yolunu vurmada... Tenden aşağı inip ayrılmayan can, yol azıtır gider! Senin canın da arşın ayrılığı ile yoksulluğa düş̧ü̧ş. Teninse diken aşkryla deveye dönmüşs! Can, yücelere kanatlar açmada. Ten, tırnaklarıyla yere sarılmada!" (1965: IV, 1543-1545) diyerek açıklar.

Bu beyitlerinde Mevlânâ, ten ile nefsi, can ile aklı, diken ile de dünyevî ve nefsanî istekleri sembolize etmiştir.

\section{Katır, At}

Mevlânâ, nefsin Allah'a ibadet ve emirlerine itaatten kaçtı̆̆ını ve bu surette kendisine nimetler verene nankörlük yaptığını anlatmak için "katır" metaforunu kullanır. Mesnevîde anlatılan hikâyede yükten kaçan katırın sahibi;

"A sersem, her tarafta eşek avlamak üzere sinmiş bir kurt var. Şimdi gözümden kayboldun mu her yandan kuvvetli bir kurt çıkagelir. Kemiklerini şeker gibi ezer, ufalar. Artık bir daha diriliği göremezsin bile! Hadi kurdu bir tarafa bırak. Otsuz kalırsın ya! Ateş, odun olmadı mı söner gider. Kendine gel de sahipliğimden kaçma, yükün ağırlı̆̆ından çekinme. Senin canın benim." diye ardına düşer, koşar durur! (Mevlânâ 1965: IV, 1997-2001)

Mevlânâ katır sahibinin sözlerini bu şekilde hikâye ettikten sonra nefsî isteklerinin peşinde koşarak Allah'ın emirlerini yerine getirmekten uzak duran insana şöyle seslenir:

"Sen de bir katırsın. Çünkü nefsin üstün. A kendisine tapan, hüküm üstünündür." (Mevlânâ 1965: IV, 2002)

Mevlânâ katırın sahibinin ona "Yanıma gel." demesinden hareketle Allah'ın Kur'an'da; "De ki: "Geliniz..." (Âl-i İmrân 3: 64) emrini işari bir bakış açısıyla yorumlar. Ayette geçen "Teâlev" ifadesinin Arapçada atları çağırmak için kullanılan bir kelime olduğunu söyleyerek,

"Fakat ululuk ıssı Allah, sana "Eşek" demedi "At" dedi... Arap, arap atına “Taal” der." (1965: IV, 2003) der.

Mevlânâ, "Kul teâlev..." ayetini ise şöyle açıklar:

"Cefakâr nefs katırlarını bakmak, yola getirmek için Mus-

tafa, Hakk'ın imrahorudur. Kerem ve ihsan çekişiyle "Kul teâlev..." dedi... "Gelin de sizi riyâzetle terbiye edeyim." dedi. "Azgın ve serkeş atları alıştırı, yola getiririm ben... Siz, kaidesiz, nizamsız gitmektesiniz; sözüme uyun da rahvan gidin. Bu su- 
retle de uysal bir hale gelin, padişahın bineceği bir at olun! "

(1965: IV, 2005-2009)

Anlaşılacağı üzere Mevlânâ, nefsi, yükten kaçan bir "katır"a benzetir. (Konuk 2009b: 43) Hikâyedeki katırın sahibi, kulun yaratıcısı olan Allah'tır. Katırına "katır" demeyip "arap atı" ismini koyan da yine Allah'tır. Katır ve atları terbiye edip evcilleştiren de Allah'ın Rasûlü Hz. Muhammed'dir. Mevlânâ'nın "padişahın bineceği at" hâline gelmekten kastı da nefs terbiyesi ile olgunluğa erişmektir. (Mevlevî 1967: XIII, 525)

Mevlânâ nefsin, aklın tersi istikametinde istekleri olduğunu ifade etmek içinse "ters giden at" metaforunu kullanır. Mesnevîde anlatılan hikâyeye göre bir kişi bir beyden evine gitmek üzere bir at ister. Bey de ona bir atı göstererek "Şu atı al" der. O, "Onu istemem. $\mathrm{O}$ at pek huylu, geri geri gidiyor" deyince bey; "Sen de kuyruğunu gideceğin yöne çevir" diyerek karşılık verir. Hikâyenin sonunda Mevlânâ;

"Senin nefs atının kuyruğu da şehvettir. Bu sebepten, o kendisine tapan, geri geri gider. Şehvet, sana aslından kuyruk olduysa o şehveti çek çevir, ahirete şehvetlen. Şehvetini yemeden içmeden kestin mi, şehvet yüce akıl cihetine düşer, oradan baş gösterir. Hani bir ağacın kötü dallarını budarsın da iyi dallarından dal budak verir, o dallar kuvvetlenir ya. Kuyruğunu o tarafa çevirdin mi geri geri gitse bile sığınılacak yere kadar varir, dayanır." (1965: VI, II2I-II25) der.

Mevlânâ nefsin insan için itici bir güç olduğunu savunur. Bu düşüncesini de "at" metaforuyla anlatır. At, üzerine bineni uzak mesafelere kısa bir zamanda götürür. Nefs de tıpkı bir at gibi üzerine bineni taşır ve uzak mesafelere götürür. Ancak nefsin özelliği geri geri gitmesi yani aklın ve dinin istikametinin zıddına bir güzergâh takip etmesidir. Onun yönü hep bedensel zevkler ve dünyevi arzulardır. İnsana düşen nefsin taşıyıcılık gücünden faydalanması ve -nefs istemese de- onun vasıtasıyla akıl ve din istikametine doğru yol almasıdır. (Konuk 2008d: 377)

Mevlânâ terbiye edilmiş nefsi, sahibine râm olmuş, hızlı ve doğru giden ata benzetir. Böyle bir atın sahibi makam-ı maksuda çarçabuk varır. Hz. Musa (a.s.)'ın süratle gitmesini (Tâ Hâ 20:83) işarî bir yorumla açıklayan Mevlânâ, bununla, terbiye olmuş bir nefs sahibinin maksadına çok hızlı bir şekilde ulaşacağını anlatmak istemektedir:

"Ne mutludur binicisine râm olan ve doğru giden atlara. Onlar, ne geri giderler, ne huysuzluk ederler. Allah Kelim'i Musa gibi hızlı hızlı gider, bir kilim gibi Bahreyn'e kadar varır, yayılır. Musa'nın gittiği yol, tam yedi yüz yıllık yoldu, o sevda ile bu kadar uzun yolu aştı." (1965: VI, 1126-1128) 


\section{Gulyabani}

Mevlânâ, nefsin korkunçluğunu anlatmak üzere "gulyabani" metaforundan yararlanır. İnsanın her an Rabbine dua ile yalvarmasının gerekliliğini anlatarak, hangi halde olursa olsun kulun duasına Allah'ın icabet edeceğini izah eder:

"Allah, "Beni çağırdın mı, suçlu da olsan, putperest de olsan ben, yine icabet ederim. Onun için duadan hiç çekinme, hiç usanma. Dua, nihayet seni gulyabani nefsin elinden kurtarır." demiştir." (Mevlânâ 1965: III, 756-757)

Mevlânâ nefsi, insanı esir etmiş bir gulyabaniye benzeterek, insanlar bu gulyabani nefsten, ancak Allah'ın inayeti ve yardımıla kurtulabileceklerini, Allah'ın inayetine ve nusretine kavuşmanın yolunun ise dua olduğunu belirtmektedir. (Konuk 2008b: 210)

\section{Eşya ve Diğer Figürler}

\section{Kılıç, Hançer}

Mevlânâ nefsi, kılıca benzetir. Eğer kişi kılıcı kullanmasını bilmiyorsa veya onu kullanacak bir güce sahip değilse düşmanı onu bu kılıçla öldürebilir. Bu durumda bulunan bir insan, düşmanın, kılıcını alıp kendisini öldürmemesi için kılıcını kırmalı veya saklamalıdır:

"Bu silah, bana düşman olacak. Onun için kılçla kalkanı kuyuya atıyorum. Ne kolumda kuvvet var, ne dayanacağım bir yer. Kılıcımı atmazsam düşmanım elimden alır onunla beni yaralar... Kuvvetim kudretim yok, iyilige de meyledemiyorum. Bunu gördüm, düssmanımı da gördüm, derhal silahımı kırdım. Bu suretle de onun bana üstün olmamasına, hançerimin kendime vebal olmamasina gayret etmiş oldum." (Mevlânâ 1965: V, 65567I)

Mevlânâ bu beyitleriyle nefsine hakim olamayıp Allah'ın emirlerine itaatte onu kullanamayan insanı, elindeki kılıcı kullanamayan zayıf ve beceriksiz bir savaşçıya benzetir. (Konuk 2009c: 234) O, böyle zayıf ve beceriksiz savaşçının elindeki kılıcı atmasını da insanın nefsinin isteklerinden vazgeçmesi olarak açıklar. (Mevlevî 1976: XIV, 19ı-2) Ona göre kişi nefsini Allah’a itaatte kullanamıyorsa hiç olmazsa nefsinin isteklerini terk etsin de düşmanı olan şeytan, kılıç mesabesinde olan bu nefsi kullanarak insanı yaralayamasın.

Mevlânâ, nefsini Allah'ın emirlerine itaatte güzelce kullanan bir insanı elindeki kılıça maharetli bir biçimde savaşan ve zafere ulaşan mücahide benzeterek şöyle der:

"Eğer aklım olsaydı da beni men etseydi kılıç, elimde bir zafer vasıtası olurdu." (1965: V, 655-671) 
Bu ifadelerden de anlaşıldığı gibi Mevlânâ, insanın aklına tabi olarak nefsini Allah'ın emirlerini yerine getirmede kullanması durumunda nefsinin onu ulvî maksatlara ulaştıracak bir vasıta haline geleceğini düşünür. (Konuk 2009c: 233)

\section{Ayna}

Mevlânâ nefsin mertebelerinden olan nefs-i mutmaine'yi açılamak üzere “ayna” metaforunu kullanır. İnsanın kötü düşüncelerle mutmain nefsinin saflığını ve temizliğini bulandıracağını düşünen Mevlânâ, kötü düşünceden uzaklaşmayı salık verir:

"Bırak bu düşünceyi! Nefs-i mutmainnenin saflğğ ve temizliği, düsünncelerle bulanır. Nitekim aynanın yüzüne bir şey yazar, yahut bir şekil yaparsın, sonra temizlesen de yine bir iz, bir noksan kalır. Nefs-i mutmainnenin yüzünü düşünce tırnakları yaralar. Kötü düşünceyi zehirli tırnak bil. Bu tırnak, derinleştikçe can yüzünü tırmalar." (1965: V, 555-559)

Dolayısıyla Mevlânâ, nefs-i mutmainne'yi bir aynaya, kötü düşünceleri de ayna üzerine yazılmış yazıya veya yapılmış bir şekle benzetir. (Mevlevî 1976: XIV, 162) Ona göre aynanın üzerindeki yazı temizlense bile yine de bir iz kalır. Buradan hareketle Mevlânâ, kötü düşüncelerin daha sonra giderilse bile nefs-i mutmainne üzerinde izleri kalacağını ifade eder. (Konuk 2009c: 200)

\section{Gölge}

Mevlânâ, nefsin, her an insanla birlikte olan bir düşman olduğunu, insanın nefsinden kaçması veya kurtulmasının mümkün olmadığını açıklamak üzere "gölge" metaforundan yararlanır.

"Damarım oynadığı sürece kaçacağım ama adamın kendisinden kaçması kolay olur mu? Başkasından kaçan, ondan kurtulunca sükuna erer, karar kılar. Halbuki benim düşmanım da benim, benden kaçan da ben. Şu halde işim kıyamete kadar boyuna kaçmaktır. Adama kendi gölgesi düşman olursa ne Hint'te emin olur, ne Huten'de." (Mevlânâ 1965: V, 658-67I)

Beyitlerden de anlaşılacağı üzere Mevlânâ, nefsin insana düşman oluşunu kişinin kendi kendine düşman oluşuyla bir tutar. İnsanın düşmanından kaçması kolaydır ancak kişinin kendisinden kaçması mümkün değildir. (Konuk 2009c: 237)

\section{Perde}

Mevlânâ nefsin eşyanın hakîkatini görmeye engel oluşunu anlatmak için "perde" metaforunu kullanır:

"Yarabbi, bu ihsan bizim işimiz değil. Senin lütfun, gizli lütfe yol göstericidir. Ey düşkünlerin ellerini tutan, elimizi tut. Bizi satın al. Perdeyi kaldır, perdemizi yırtma." (Mevlânâ 1965: Il, 2432) 
Bu beyitlerinde Mevlânâ "Perdeyi kaldır." derken nefsin, hakîkatleri görmeye engel bir perde olduğunu anlatmak istemiştir. Ona göre, "Perdenin kaldırılması" nefsin terbiye edilerek Hakk'a vuslat yolunda bir engel olmaktan çıkarılmasıdır. (Konuk 2007: 169) Mevlânâ, "Perdemizi yırtma." derken ise perdeyi farklı bir metaforik anlamda kullanarak "Bizi utandırma." demek istemiştir.

\section{Gözde Biten Kıl}

Mevlânâ nefsi, "gözde biten kıl"a benzetir. Ona göre "Allah tapusunu, Allah dergâhını" görmek isteyen insanın gönül gözünde biten kılı gidermesi gerekir:

“Kardeş, onun köşkünü nasıl görebilirsin? Gönül gözünde

kıl bitmiș! Gönül gözünü kıldan ve hastalıtan arıt, sonra köşkünü görmeyi gözet. Kimin can, heveslerden arınmışsa derhal tertemiz Allah tapusunu, Allah dergâhını görür. Muhammed, bu ateşten, bu dumandan temizlendiğinden nereye yüz çevirse orada Allah cemalini gördü. Seni kötülüğe sevk eden vesveselere yoldaş oldukça "Semme vechullah"” (Bakara 2: 115) nasıl bilebilirsin?" (Mevlânâ 1965: l, 1395-1399)

Bu beyitlerinde Mevlânâ, "gözde biten kıl" metaforuyla nefsanî hevesleri kast etmektedir. Ona göre Allah'n tapusunu görebilmenin yolu gönül gözünde biten kıl mesabesindeki nefsî arzulardan kurtulmak gerekir. (Konuk 2009a: 4223) Mevlânâ, gönlünü arındıran insanın her ne tarafa yönelirse orada Allah'ı bulabileceğini ifade eder ve bu düşüncesine delil olarak da Hz. Peygamber (s.)'i gösterir.

\section{Gözün Önüne Konulan Parmak}

Mevlânâ nefsi insanın "gözünün önüne konulan parmak"a benzetir. (Mevlevî 1976: 3, 734; Konuk 2009a: 424) Ona göre, gözünün önünde parmak bulunan bir kimse nasıl ki hiçbir şey göremezse, nefsini arındırarak ondan kurtulamamış insan da manevî âlemdeki hakîkatleri göremez:

“Kimin kalbinde kapı açlırsa gönül gögünde yüzlerce güneş görür. Yıldızların içinde ay nasıl görünürse başkaları arasında Allah da öyle görünür. Fakat iki parmağın iki gözünün üstüne koy; bir şey görebilir misin? Insaf et! Sen görmesen de dünya yok değildir. Kusur, ancak şom, nefs parmağında. Kendine gel! Gözünden parmağını kaldır da ne istiyorsan gör." (Mevlânâ 1965: l, 1400-1404)

\section{Sağlam Kilit}

Mevlânâ, nefsi terbiyenin çok güç bir iş olduğunu ve bu hedefin gerçekleşmesinin ancak Allah'ın yardımıyla mümkün olabileceğini anlatmak için "sağlam kilit" metaforunu kullanarak şöyle der: 
"Ey muhabbet ihsan eden muhabbetli Allah, böyle sağlam bir kilidi, senin fazlından başka kim açabilir?" (1965: 11, 2435)

Dolayısıyla Mevlânâya göre nefs öyle sağlam bir kilittir ki bu kilit ancak Allah'ın fazl ve ihsanıyla açılabilir.

\section{Kuvvetli Bă̆}

Mevlânâ nefsi, insanı sıkı sıkıya sarmış kuvvetli bir bağa benzetir. (Konuk 2007: 169) Ona göre insan, bu bağdan sadece kendi çabası ile kurtulamaz. İnsan, Allah'ın yardımı ve ihsanı ile bu bağdan kurtulup selamete kavuşabilir:

"Bizi bu murdar nefsten kurtar. Çünkü bıçağı kemiğimize kadar dayandı. Ey tacı, tahtı olmayan padişah, bizim gibi biçarelerden bu kuvvetli bağı kim çözebilir?" (Mevlânâ 1965: II, 2435)

\section{9. Çakmak}

Mevlânâ, nefsin tabiatında kötülük taşıdığını ve bu özelliğin onda arızî bir haslet olmayıp onun aslî bir sıfatı olduğunu düşünür. Bu düşüncesini açıklamak için "çakmak" metaforunu kullanarak şöyle seslenir:

"Nefs; demir ve taştan yapılan çakmaktır...Taş ve demir (çakmak), su ile söner mi? Âdemoğlu'nda, bu ikisi oldukça ne vakit ve nasıl emin olur? Taş ve demir, ateşi içlerinde tutarlar, su onların ateşine işleyemez, tesir edemez. Irmak suyundan haricî ateş söner. Fakat taş ve demirin içine su nasıl girer?" (1965: l, 774-775)

Bu beyitlerde nefsi bir çakmağa benzeten Mevlânâ, ateşin çakmağın içinde olduğunu bu nedenle de haricî suların çakmağın içinde meknuz bulunan ateşe tesir edemeyeceğini anlatır. (Mevlevî 1976: 2, 460) Buradan hareketle nefs terbiyesinin ancak gönüllere işleyen tesirli sohbeti ile bir mürşid eliyle ve Allah'ın yardımı ve ihsanıyla mümkün olabileceğine işaret eder. (Konuk 2009a: 272-3)

\section{Akrebin İğnesi, Yılanın Zehirli Dişi}

Mevlânâ, nefsi, "akrebin iğnesi" ve "yılanın zehirli dişi"ne benzetir. Nasıl ki iğnesi çıkarılmış bir akrep veya zehirli dişi sökülmüş bir yılan, -tehlikesiz bir hale geldiğinden- öldürülmekten kurtulursa terbiye edilmiş bir nefsin sahibi de ahirette cezadan kurtulmuştur:

"Baş kesmek nedir? Dünyada nefsi öldürmek, nefsin dileklerini terk etmek. Bu da öldürülmekten kurtulsun diye akrebin iğnesini çıkarmak gibidir. Taşla tepelenme belasından kurtulsun diye yılanın zehirli dişini sökersin ya! Nefsi, pirin gölgesinden başka hiçbir şey öldürmez. $O$ nefs öldürenin eteğine sımsıkı sarıl. Eteğini sıkıca tuttun mu, bu, Allah tevfikidir." (Mevlânâ 1965: II, 2511-2515) 
Beyitlerden de anlaşılacağı üzere Mevlânâ'ya göre nefsi öldürmek nefsin isteklerini terk etmek ve bu surette onu terbiye etmekten ibarettir. (Konuk 2007: 189) Nefs terbiye edilince iğnesi çıkarılmış bir akrep gibi başkalarına zarar veremeyecek bir hale gelmiş olur. (Mevlevî 1976: VIII, 778-9)

\section{Zehir}

Mevlânâ, nefsi, insanı hastalandıran "zehr"e benzetir. Ona göre insan zehirlenip hasta olunca nasıl ki tüm nimetler ve güzel yiyecekler ona acı ve kötü gelirse nefs zehriyle hastalanmış kişi için de bütün ilahî beyanlar ve gönül ferahlatıcı nefesler çirkin ve acı görünür:

"Nefs zehirleriyle hastalanmış, hastalığa tutulmuşsan eline ne alir, elini nereye atar, neye sahip olursan hastalığa alet olur, onu da berbat edersin! Eline mücevher alsan, taş olur, gönül sevgisine yapısssan savaş olur... $O$ (hastalık) yüzünden nimetler, umumiyetle illet olur. Hastalıkta yenen yemek insana hiç kuvvet verir mi? Ey inatçı, önüne nice güzelim nimetler geldi de hepsi kötüleşti, saf olanlar bile bulandı gitti! $O$ illet durdukça şeker bile zehir kesilir. Her güzel ve tath şey, insana kötü ve acı gelir. Insan ab-ı hayat içse ateş sanır... O illetin zehri bütün canlara sirayet eder. $O$ illeti derhal geçirmeye çalışmak gerek." (Mevlânâ, 1965: III, 2677-2698)

O hâlde Mevlânâya göre nefs zehirdir ve insan bu zehrin tesirini kendisinden gidermelidir. İnsan nefsini terbiye etmek suretiyle ancak bu zehrin tesirinden ve manevî hastalıktan kurtulabilir. Tabidir ki her şeyden önce insan hasta olduğunu kabul etmeli ve dışarıda var olduğunu vehmettiği bütün acılık ve çirkinliklerin aslında hastalığının bir ispatı olduğunu itiraf etmelidir. (Konuk 2006a: 81)

\section{Zehirli ot}

Mevlânâ, nefsin insan için verebileceği zararları anlatmak için "zehirli ot" metaforunu kullanarak şöyle der:

"Bu kuvvetli zehrin bittiği ovada tiryak da bitmiştir ey oğul! Tiryak, sana 'Gel, beni kendine siper et. Ben, sana zehirden daha yakınım. Onun sözü sihirdir, seni yıkar harap eder. Benim sözüm de sihir ama onun sihrini defeder.' der!" (1965: III, 4066-4076)

Beyitlerden de müşahede edileceği üzere Mevlânâ, nefsi "zehirli ot"a, nefsi terbiye eden mürşidi de zehirli otun tedavisini sağlayacak olan "tiryak"a benzetir. (Konuk 2006a: 442-3) Ona göre, insan yanlışlıkla zehirli bir ot yerse hastalanır ve tedavi edilmesi gerekir. Bu tedavi de ancak bu zehrin antidotu olan başka bir otla yapılabilir. Zehirli otun tiryakı olmadan zehirlenmenin tesiri giderilemez. 
Nefs zehriyle hastalanmış kişinin tedavisi de ancak nefs zehrinin tiryakı olan şeyh vasıtasıyla yapılabilir. (Mevlevî 1976: XI, 1060)

\section{3. Üç Köşeli Diken}

Mevlânâ, nefsle mücadelede asla bir uzlaşmanın olamayacağını düşünür. Nefsi üç köşeli bir dikene benzeten Mevlânâ, konuyla ilgili olarak,

"Nefs, üç köşeli dikendir, ne çeşit koysan sana batar, ondan kurtulmana imkân mı var? Heva ve hevesi terk etme ateşini vur şu dikene." (1965: 11l, 371376) der.

Dolayısıyla Mevlânâ'ya göre nefs asla verilene razı olup kanaat etmez. Nefse verilecek hiçbir taviz onu tatmin etmez. Bu yüzden insan, nefsiyle anlaşmayı muhal bilmeli ve onunla savaşmaktan başka bir yolu olmadığını kavramalıdır.

Mevlânâ, nefsin üç köşeli olmasını ise onun gönlünün hiçbir şeyle razı edilemeyeceğiyle açıklar. Ona göre nefse ne verilirse verilsin asla kanaat etmez, verilene razı olmaz. O bu durumu şöyle ifade eder:

"Insan yazın kışı ister, fakat kış geldi mi bundan da vazgeçer, istemez. Bir hâle katiyen razı olmaz. Ne darlıktan hoşlamir, ne genişlikten, bolluktan. Geberesi insan, efendisine ne de kâfirdir ya... Hidayete nail oldu mu tutar, inkara sapar." (1965: III, 371-376)

\section{Pinar Suyu}

Mevlânâ, nefs ile müşriklerin tapındığı "put"u karşılaştırır. O, "put"u bir testide bulunan bir miktar kara suya, nefsi de o testideki "kara suyun kaynağı"na benzetir:

"Put, bir testide gizli kara sudur. Nefsi, muhakkak olarak o kara suya pınar bil. O, yontulmuş put, kara sel gibidir. Put yapan nefs, anayolda bir pınardır. Bir taş parçası yüz testiyi kırar ama pinar suyu durmadan kaynar. Put kirmak kolay, gayet kolaydır. Fakat nefsi kolay görmek cahilliktir." (1965: l, 776779)

Beyitlerde Mevlânâ, küçük bir taşın yüzlerce testiyi kırmasıyla, zahirî putları kırmanın kolaylığını ifade ederek, insanın içindeki nefsi terbiye etmek çok zor bir iş olduğunu anlatır. (Konuk 2009a: 272) Çünkü nefs, put yapıcıdır. Her gün binlerce put yapar. Mevlânâ, pınar suyunun durmadan kaynamasıyla ise nefsin her an bir kötülük peşinde olmasını kast eder. (Mevlevî 1976: 11, 462)

\section{Ana Put}

Mevlânâ, nefsi "ana put"a benzetir. O, nefsin, "zahirî putların anası" olduğunu izah etmek için bir Yahudi padişahının Hz. İsa'ya inanan samîmî Hıristiyan- 
$98^{* \text { TAED }} 48$ Adem ÇATAK

ları dinlerinden döndürmek için ateş yaktırması ve ateşin yanına, "Kim puta secde ederse ateşten kurtuldu" diyerek bir put diktirmesini anlatır.

"Ateşin yanına bir put dikti. "Kim bu puta taparsa kurtulur. Secde etmeyen, ateşin tam ortasına oturur" dedi. $O, b u$ nefs putunun cezasını vermeyince nefs putundan, başka bir put doğdu. Putların anası nefsinizin putudur. Çünkü o put yılan, bu (nefs) put(u) ejderhadir." (1965: l, 770-773)

Anlaşılacağı üzere Mevlânâ nefsi, tüm zahirî putların anası olan bir puta benzetir. (Konuk 2005: 269) Nefs putu cezalandırılmayınca tapılacak bir çok putlar doğurur. (Mevlevî 1976: 11, 458) Gerçekten de tarih boyunca puta tapındığını söyleyen müşrikler aslında sadece kendi heva ve isteklerine yani nefs putuna tapmışlardır.

\section{Cehennem}

Mevlânâ nefsin kanaatsizliğini anlatmak için "cehennem" metaforunu kullanır.

"Ey oğul, nefsin misal ve suretini istersen yedi kapılı cehennemin kıssasını oku!" (1965: 1, 780) diyen Mevlânâ, nefsin doymayışını şöyle anlatır:

"Cehennem, bu nefstir; cehennem, bir ejderhadir ki harareti denizlerle eksilmez. Yedi denizi içer de yine kocakarıya benzeyen nefsin harareti ve coşkunluğu azalmaz... Hak'tan ona şu nida gelmedikçe bu kadar azaba da kanaat etmez: "Doydun mu" denir. $O$, kurt ve sirtlan gibi "Hayır, doymadım" der. İşte sana ateş, işte sana hararet! Bütün bir âlemi, bir lokma edip yutar da yine midesi "Daha fazla yok mu" diye bağırrr. Nihayet Hak, onun üstüne Lâmekân âleminden ayağını koyar da iște o vakit derhal sakinleşir. Bizim nefsimiz de cehennemin bir parçasıdır. Onun için cüzler daima küllün tabiatındadır. Nefsi öldürecek ayak da ancak Hakk'n ayağıdır." (1965: l, 1376-1384)

Dolayısıyla Mevlânâ'ya göre nefs, cehennemin doymayışı gibi bir aç gözlülüğe sahiptir. (Mevlevî 1976: 2, 463) Nefsi, isteklerinin karşılanması yoluyla teskin etmek mümkün değildir. $\mathrm{O}$, hep daha fazlasını ister. Onun için nefsi teskin etmenin yolu onun oburluğuna karşı Allah'tan yardım istemek ve onun şerrinden Allah'a sığınmaktır. Zaten nefsi terbiye edecek en etkili vasıta da Allah'ın inayetidir. (Konuk 2009a: 272, 417)

Mevlânâ, "cehennem" metaforunu başka bir bağlamda da kullanarak, nefsin kötülüğünü ve sahibine zarar vericiliğini izah etmek için nefsi cehenneme benzetir:

"Senin duygun, fikrin hep ateşten. Şeyhin duygusu ve fik$r i$ ise güzel nur. Onun nur suyu ateşe damladı mı ateşten "cız, cız" sesi çıkmaya başlar. O cızladıkça sen ona "Öl, bit." de ki, 
bu nefs cehennemin sönsün. Sönsün ki senin gül bahçeni yakmasın; senin adalet ve ihsanını söndürmesin. O söndükten sonra ne dikersen biter... Lâleler, ak güller, marsamalar çıkar." (1965: II, 1250-1255)

Beyitlerden de anlaşılacağı üzere Mevlânâ, nefsi cehenneme, şeyhin nurunu da cehennemin üstüne damlayan suya benzetir. Ona göre cehennemin ateşi şeyhin nurundan söndüğü gibi (Suyutî 1373: 1,133) nefs cehennemi de şeyhin irşadıyla yavaş yavaş söner ve kendisindeki yakıcılık yok olur. (Konuk 2008a: 350)

\section{Sonuç}

Mevlânâ'nın nefs hakkındaki düşüncesinin temel konuları nefsin mahiyeti ve nefs terbiyesidir. Mevlânâ nefs kavramını değişik bağlamlarda açıklamak üzere metaforlardan yararlanmıştır. Mevlânâ metaforik anlatımında, derin bir tefekkür dünyası içinde tabiatın hemen her varlığını ustaca kullanmışır. Bu metaforik dilin nesnesi bazen insanlar, bazen hayvanat ve bazen de eşyalar olabilmiştir.

Mevlânâ nefsin, insan için itici bir güç olduğunu savunur. Bu düşüncesini de "at" metaforuyla anlatır. At, üzerine bineni uzak mesafelere kısa bir zamanda götürür. Nefs de tıpkı bir at gibi üzerine bineni taşır ve uzak mesafelere götürür. Mevlânâ terbiye edilmiş nefsi, sahibine râm olmuş, hızlı ve doğru giden ata benzetir. Böyle bir atın sahibi makam-ı maksuda çarçabuk varır.

Mevlânâ, nefsi, eşyanın hakîkatini görmeye engel olan bir "perde" ye benzetir. "Ey düşkünlerin ellerini tutan, elimizi tut. Bizi satın al. Perdeyi kaldır, perdemizi yırtma." diyen Mevlânâ, "Perdeyi kaldır." derken nefsin, hakîkatleri görmeye engel bir perde olduğunu anlatmak ister. Ona göre, "perdenin kaldırılması" nefsin terbiye edilerek Hakk'a vuslat yolunda bir engel olmaktan çıkarılmasıdır.

Mevlânâ, nefsin terbiye edilmesini kurban kesmeye benzetir. $\mathrm{O}$, nefsin başının kesilmesinin can/aklı mahvolmaktan kurtulmasına vesile sayar. Ona göre nefsin terbiye edilmesi, Hz. İbrahim (a.s.)'ın, oğlu Hz. İsmail (a.s.)'ı kurban etmesi hadisesine benzer. Canı/aklı Hz. íbrahim (a.s.)'a, nefsi ise Hz. İsmail (a.s.)'a benzeten Mevlânâ'ya göre bir kurban kesilip ruhunu teslim edince nasıl ki hiçbir nefsani isteği kalmazsa nefs de ancak kurban edilmek suretiyle aşırı isteklerinden arındırılabilir.

Mevlânâ, manevi dirilişe ulaşılabilmenin nefsin terbiye edilmesine bağlı olduğu düşüncesine sahiptir. $\mathrm{O}$, bu düşüncesini, "boğazlanan öküz" metaforuyla açıklar. Mevlânâ, Hz. Musa (a.s.) zamanında gerçekleşen bir katl olayının aydınlatılması için bir ineğin boğazlanarak maktule vurulması ve bu suretle maktulün dirilerek kendisini öldürenleri haber vermesi olayını anlatır. Mevlânâ, öküzün öldürülmesi ve kuyruğuyla ölüye vurulması neticesinde maktulün dirilmesinden hareketle nefsin öldürülmesi sonucu insanın manevi bir dirilik kazanacağını düşünür. 
Mevlânâ'ya göre "öküz kesmek” nefsi eğitmek, yenmek ve alt etmek demektir. "Öküz kesmek yol şartlarındandır" derken Mevlânâ, nefs terbiyesi yoluyla onun her türlü kötülük, kabalık ve çirkinliklerinin giderilmesinin tasavvufun temel esasları arasında yer aldığını metaforik bir dille belirtmek istemiştir.

Mevlânâ, nefsin hakîkatinin anlaşılmasının ve onun terbiye edilmesinin ancak bir şeyhin yardımıyla gerçekleşebileceğini izah etmek üzere haksızken davacı olan öküz sahibi sembolüyle açıklar. Nefsin terbiyesinde şeyhin rolünü bir başka biçimde anlatmak isteyen Mevlânâ, "tuzlaya düşmüş eşek" metaforundan yararlanır. "Ölmüş eşek tuzlaya düşünce eşekliği, murdarlığı bir tarafta kalır" ifadeleriyle Mevlânâ, "ölmüş eşek" metaforuyla hakîkat bilgisinden habersiz, manen ölü nefsi, "tuzla" metaforuyla ise insanı hevâ ve heveslerinden arındırarak nefsini tezkiye etmesine yardım eden mürşidi simgelenmiştir.

Ejderha olan nefsin, ancak bir mürşidin terbiyesiyle etkisiz hâle getirilebileceğini düşünen Mevlânâ, bu düşüncesini ifade etmek için de nefsi, ejderhaya, şeyhi de ejderhanın gözüne tutulan zümrüde benzetir. Ona göre nasıl ki zümrütten çıkan şualar yılanın gözünü kör ediyorsa bir mürşidin kalbinden akseden ilahî nurlar ve feyizler de insanın nefsinin gayr-i meşru isteklerini yok eder.

Mevlânâ nefse ihsanda bulunmanın yanlışlı̆ıını ve ona cefa edilmesi gerekliliğini açıklamak için nefsi, aşağılık ve kötü huylu bir kâfire benzetir. Ona göre nefse iyilik etmek onu daha da azgınlaştıracaktır. Bu nedenle nefs terbiyesinde riyâzet kaçınılmaz bir araçtır.

Nefsi, "yükten kaçan eşeğe" benzeten Mevlânâ, onu terbiye etme yollarından biri olarak da "sırtına sabır ve şükür yükünü yükleme"yi de salık verir. Yine o, nefsle mücadelede kararlı ve cesaretli olunması prensibini, "eşeğe çıplak binilmesi" metaforuyla açıklar.

Mevlânâ, insanın, nefsini terbiye ettiğini ve artık kendisine kötülük yapmayacak bir hâle kavuştuğunu asla iddia etmemesini salık verir. Çünkü nefsin teslim olmuş görüntüsü altında insana hazırladığı gizli bir hile ve düşmanlık bulunabilir. Bu düşüncesini nefsi riyâkâr bir münâfığa benzeterek dillendirir.

Mevlânâ, nefsi bir köpeğe benzeterek terbiye edilse bile tabiatı icabı her an tekrar kötülüğe dönme huyuna sahip olduğundan daima kontrol edilmesi gerektiğini düşünür. Ona göre nefse değer verilmemeli ve nefs aşağılanmalıdır.

Yine Mevlânâ "donmuş ejderha" metaforuyla nefsini terbiye ettiği zannına kapılan ham sûfinin hâlini betimler. Ham sûfî, yapmış olduğu bir takım riyâzet, zikir, tefekkür vb. neticesinde nefsini tezkiye ettiğini sanır. Nefsine tam manasıyla hakim olduğunu düşünür. Aslında nefsi hâlâ diri ve onu kötülüklere sürükleyebilecek kadar güçlüdür. Ancak nefs, eline firsat geçmediğinden terbiye olmuş hâline bürünür. Mevlânâ "donmuş ejderha" metaforuyla aynı anlamda olmak üzere "kuyuya hapsedilmiş ejderha" metaforunu da kullanır. Bu anlatımlarıyla Mevlânâ, ejderhanın açık alanda olmasıyla, insanın elinde mal, makam ve güç bulunması 
anlamını, ejderhanın kuyuda hapsedilmiş olmasıyla ise insanın fakirlik, zayıflık, hastalık vb. gibi güçsüz durumda bulunmasını kasteder.

Bu çalışma, nefsin mahiyetini, nefs tezkiyesinin önemini, nefs terbiyesinin usul ve inceliklerini, Mevlânâ'nın metaforik ve edebî diliyle, izah etmeyi başarabilmişse amacına ulaşmış sayılabilir.

\section{KAYNAKÇA}

ALTıNKAYNAK, Erdoğan. "Yer Altı Diyarının Kartalı”. Hacı Bektaş Velî Dergisi, Yıl: 2003, sayı: 26, ss. 21-23.

ARMUTAK, Altan. "Doğu Ve Batı Mitolojilerinde Hayvan Motifi Il. Sürüngenler, Balıklar, Kanatlılar ve Mitolojik Hayvanlar". İstanbul Üniversitesi Veteriner Fakültesi Dergisi, yıl: 2004, sayı: 30 (2), ss. 143-15.

AYDIN, ibrahim Hakkı. "Bir Felsefî Metafor 'Yolda Olmak". Din Bilimleri Akademik Araştırma Dergisi, 2006, c. Vl, sayı: 4, s. 10.

BEYHAKî, Ahmed b. Huseyn, b. Ali b. Musa. Kitabu'z-Zühdi'l-Kebir. Müessesetü'l-Kütübü'sSekafiyye, Beyrut, 1996.

CEBECiOGLLU, Ethem. "Seyyid Burhaneddin Muhakkık-1 Tirmizi'nin Bazı Tasavvufi Kavramlara Getirdiği Metaforik Yaklaşımlar". Ankara Üniversitesi ilahiyat Fakültesi Dergisi, 1998, cilt: XXXVIII, s. 128.

ÇAĞBAYIR, Yaşar. Orhun Yazıtlarından Günümüze Türkiye Türkçesinin Söz Varlı̆̆ Ötüken Türkçe Sözlük. Ötüken Neşr., İstanbul, 2007, c. III.

ÇETINKAYA, ülkü. "Divan Şiirinden Örneklerle Mübalağa Sanatının Mizahla ilişkisi”. Turkish Studies, International Periodical For The Languages, Literature and History of Turkish or Turkic, Vol. 6/2 Spring 2011,p.39-74.

ÇiçEK, Hasan. "Kadîm Ü̈ç Felsefe Problemi Bağlamında Mevlânâ'nın Mesnevîssinde Metaforik Anlatım”. Ankara Üniversitesi ilahiyat Fakültesi Dergisi, 2003, cilt: XLIV, sayı: 1, s. 296.

ÇUBUKÇU, ỉbrahim Agah. "Birunî”. Ankara Üniversitesi ilahiyat Fakültesi Dergisi, 1985, cilt: XXVIl, ss. 89-95.

DEMiRCi, Mehmet. “Ölümdeki Hayat (Tasavvuf Düşüncesinde Ölüm)”. Tasavvuf, ilmî ve Akademik Araştırma Dergisi, Ankara 2000, sayı 4,ss.9-16.

DURAK, Nejdet. Mesnevî'de Metaforik Anlatımlarda Kullanılan Hayvan Motifleri ve Felsefí Değerlendirmesi. (Uluslararası Düşünce ve Sanatta Mevlânâ Sempozyumu Bildirileri, Çanakkale, 2006), ss. 155-165.

ERDEM, Hüseyin Subhi. "Hakîkat ve Metafor". Din Bilimleri Akademik Araştırma Dergisi, 2006, cilt: Vl, sayı: 3, ss. 59-77.

GEMUHLUOĞLU, Zeynep. "Metaforların Kognitif içeriklerinin Felsefe ve Şiir Dili Açısından İncelemesi -Farabi, ibn Sina ve Rüşs Örnekleri-". Marmara Üniversitesi illahiyat Fakültesi Dergisi, 2008/1, sayı: 34, ss. 121-144.

GÜNAY, Umay. "Türk Masallarında Geleneksel ve Efsanevî Yaratıklar". Hacettepe Üniversitesi Edebiyat Fak. Dergisi, Yıl: 1983, Sayı:1, ss.21-46.

KONUK, A. Avni. Mesnevî-i Şerîf Şerhi. Kitapevi, İstanbul, (c. I, 2009a); (c. Il, 2005); (c. III, 2008a); (c. IV, 2007); (c. V, 2008b); (c. Vl, 2006a); (c. VIl, 2006b), (c. VIIl, 2009b); (c. IX, 2009c); (c. X, 2008c); (c. Xl, 2008d)

KÖKSEL, Behiye. "Halk Türkülerinde Avla ilgili Semboller". Acta Turcıca Çevrimiçi Tematik Türkoloji Dergisi, Yıl 1, Sayı 1, Ocak 2009, ss. 464-478.

MEVLÂNÂ, Celâleddin-i Rûmî. Fihi Ma Fih. (Çev. Ahmet Avni Konuk). İz Yayıncılık, İstanbul, 1994. 
$102^{* \text { TAED }} 48$ Adem ÇATAK

MEVLÂNÂ, Celâleddin-i Rûmî. Mecâlis-i Seb’a. (haz.) Dilaver Gürer, Konya Büyükşehir Belediyesi Yay., Konya, 2008.

MEVLÂNÂ, Celâleddin-i Rûmî. Mesnevî. (Çev. Veled i̇zbudak). Millî Eğitim Basımevi, Ankara, 1965.

MEVLEVî, Tahir Olgun. Şerh-i Mesnevî. Şamil Yay., ìstanbul 1976, c. 1-18.

Müslim, Ebu'l-Huseyin Müslim ibnu'l-Haccac el-Kuşeyrî en-Nisâbûrî. el-Camiu's-Sahih. İstanbul, 1332.

NESTEROVA, Svitlana. Mevlânâ'nın "Mesnevî" isimli Eserinde Metaforik Anlatımın Metafizik Boyutu. Ankara, 2011, Basılmamış Doktora Tezi.

ÖGKE, Ahmet. "Mevlânâ'nın Mesnevîsinde "Har (Eşek)” Metaforu”. Tasavvuf: illmî ve Akademik Araştırma Dergisi, 2007, yıl:8, sayı, 18, ss.19-41.

, Mevlânâ'nın Mesnevîsinde "Öküz" Metaforu”. Tasavvuf: ilmî ve Akademik Araştırma Dergisi, y1l: 9 (2008), sayı, 22, ss. 9-22.

“ibnü'l-Arabînnin Fusûsu'l-Hikem'inde Ayna Metaforu”. Tasavvuf: ilmî ve Akademik Araştırma Dergisi, 2009, cilt: IX, sayı: 23, (“ibnü’l-Arabî” Özel Sayısı - II), ss. 75-89.

ÖZBAŞ, Mustafa. "Kurtarıcı Kargadan Burnu Pislikten Çıkmayan Kargaya: Türk Halk Anlatılarında Karganın Dönüşümü". Millî Folklor, Yıl: 2010,(22), sayı: 88, ss. 57-65.

ULAŞ, Sarp Erk. (haz.). Felsefe Sözlüğü. A. Baki Güçlü vd. Ankara: 2002.

SOYSALDI, ihsan. "Mevlânâ'nın Mesnevisinde "Nefs" Kavramı." Uluslararası Mevlânâ ve Mevlevîlik Sempozyumu Bildiriler 1, Şanlıurfa, 26-28/10/2007.

SuYûTî, Celaluddin Abdurrahman b. Ebi Bekir. el-Cami'u's-Sağîr fî Ehâdis-i'l-Beşir ve'n-Nezîr. Kahire, 1373.

ŞiMŞEK, Selami. “Türk Edebiyatında ibnü'l-Arabî Methiyeleri Üzerine Bir İnceleme”. Tasavvuf illmî ve Akademik Araştırma Dergisi (ibnü'l-Arabî Özel Sayısı-1), yıl: 9 [2008], sayı: 21, ss. 389-425.

The Encyclopedia of Philosophy. Yay.: Paul Edwards. Newyork 1972,c. V.

ÜNALAN, Abdullah. "Hadislerde Metaforik Kullanım". Dicle Üniversitesi ilahiyat Fakültesi Dergisi, 2009, cilt: Xl, sayı: 1, ss. 107-140.

YAYLAGüL, Özen. "Divânu Lugâti't-Türk'de Yer Alan Atasözlerindeki Metaforlar". Milli Folklor, 2010, y1l, 22, say1 85 , ss. 112-121. 